\title{
The Applications of Molecular Hydrogen in Horticulture
}

\author{
Longna Li ${ }^{1} \mathbb{D}$, Yan Zeng ${ }^{2}, \mathrm{Xu}$ Cheng $^{2}$ and Wenbiao Shen ${ }^{1,3, *(\mathbb{D})}$ \\ 1 Laboratory Center of Life Sciences, College of Life Sciences, Nanjing Agricultural University, Nanjing 210095, \\ China; 1ln2013034@njau.edu.cn \\ 2 Air Liquide (China) R\&D Co., Ltd., Shanghai 201108, China; yan.zeng@airliquide.com (Y.Z.); \\ steven.cheng@airliquide.com (X.C.) \\ 3 Center of Hydrogen Science, Shanghai Jiao Tong University, Shanghai 200240, China \\ * Correspondence: wbshenh@njau.edu.cn; Tel.: +86-25-84-399-032; Fax: +86-25-84-396-542
}

check for

updates

Citation: Li, L.; Zeng, Y.; Cheng, X.; Shen, W. The Applications of Molecular Hydrogen in Horticulture. Horticulturae 2021, 7, 513. https:// doi.org/10.3390/horticulturae7110513

Academic Editor: Luigi De Bellis

Received: 23 September 2021

Accepted: 19 November 2021

Published: 22 November 2021

Publisher's Note: MDPI stays neutral with regard to jurisdictional claims in published maps and institutional affiliations.

Copyright: (c) 2021 by the authors. Licensee MDPI, Basel, Switzerland. This article is an open access article distributed under the terms and conditions of the Creative Commons Attribution (CC BY) license (https:/ / creativecommons.org/licenses/by/ $4.0 /)$.

\begin{abstract}
Improvements in the growth, yield, and quality of horticultural crops require the development of simply integrated, cost-efficient, and eco-friendly solutions. Hydrogen gas $\left(\mathrm{H}_{2}\right)$ has been observed to have fertilization effects on soils by influencing rhizospheric microorganisms, resulting in improvements in crop yield and quality. Ample studies have shown that $\mathrm{H}_{2}$ has positive effects on horticultural crops, such as promoting root development, enhancing tolerance against abiotic and biotic stress, prolonging storage life, and improving postharvest quality of fruits, vegetables and cut flowers. In this review, we aim to evaluate the feasibility of molecular hydrogen application in horticulture and the strategies for its application, including $\mathrm{H}_{2}$ delivery methods, treatment timing, and the concentration of $\mathrm{H}_{2}$ applied. The discussion will be accompanied by outlining the effects of $\mathrm{H}_{2}$ and the likely mechanisms of its efficacy. In short, the application of $\mathrm{H}_{2}$ may provide novel opportunities for simple and cost efficient improvements of horticultural production in terms of increased yield and product quality but with low carbon dioxide emissions.
\end{abstract}

Keywords: hydrogen gas; hydrogen-rich water; hydrogen nanobubbles; solid $\mathrm{H}_{2}$-storage material; horticultural crops; metabolism

\section{Introduction}

Horticultural crops are grown for food, medical use, and aesthetic enjoyment. They form an important part of agricultural production and contribute to food security as well as nutritional quality. The improvement in the growth, yield, and quality of horticultural crops has attracted widespread attention, especially for developing easy, cheap, and eco-friendly solutions, which is a challenge for a low-carbon society.

Hydrogen is the lightest and most abundant chemical element in the universe. Researchers have proposed that hydrogen gas $\left(\mathrm{H}_{2}\right)$ played a critical role in the origin of eukaryotes [1]. Meanwhile, the production and release of $\mathrm{H}_{2}$ has been observed in algae, animals, and plants [2-4]. Thus, it is not surprising that $\mathrm{H}_{2}$ has increasingly been attached to various biological functions in animals and plants, which have been observed during the last two decades of studies [5-7].

Despite its low mixing ratio ( $~ 530$ parts per billion by volume) in current Earth's atmosphere, $\mathrm{H}_{2}$ contributes to the homeostasis of the oxidation state in the atmosphere [8]. In the context of $\mathrm{H}_{2}$ biogeochemical cycles, the most important source of $\mathrm{H}_{2}$ for the atmosphere is methane, while other sources are non-methane hydrocarbons and photochemical oxidation. Conversely, microbial-mediated soil uptake is responsible for $\sim 80 \%$ of the tropospheric $\mathrm{H}_{2}$ losses. $\mathrm{H}_{2}$ has been shown to maintain microbial viability and activity and, in turn, driven carbon cycling [9]. Since $\mathrm{H}_{2}$ exposed soil improved plant growth, it has been proposed that $\mathrm{H}_{2}$ fertilization of soil can be attributed to $\mathrm{H}_{2}$-oxidizing bacteria in the rhizosphere [10]. Accordingly, the deliberate application of $\mathrm{H}_{2}$ might have substantial potential in agricultural benefits. 
In 2003, Dong et al. [10] observed that $\mathrm{H}_{2}$-treated soil improved growth in canola (Brassica napus) and first proposed the " $\mathrm{H}_{2}$ fertilization" hypothesis. Since then, a growing number of studies on the application of $\mathrm{H}_{2}$ in horticulture have been carried out due to its unique properties in stimulating or sustaining plant growth and development, as well as postharvest preservation in particular (Figure 1). So far, there are a total of 62 publications on horticultural $\mathrm{H}_{2}$ application from China (59), Australia (2), and Canada (1). In 2013, $\mathrm{H}_{2}$ supplied by hydrogen-rich water (HRW) was observed to enhance plant tolerance with respect to herbicide (paraquat), drought, salinity, and cold stress in alfalfa seedlings [11]. Subsequently, many additional functions of $\mathrm{H}_{2}$ have been discovered, such as promoting root development in cucumber (Cucumis sativus) [12] and tomato (Lycopersicon esculentum) [13] and alleviating heavy metal toxicity in pak choi (Brassica rapa var. chinensis) [14] and alfalfa (Medicago sativa) [15]. In addition, $\mathrm{H}_{2}$ has been shown to improve the yield and quality of daylily (Hemerocallis fulva L.) [16], as well as prolonging the shelf life and vase life of fruits and flowers including kiwifruit (Actinidia chinensis var. deliciosa) [17], lychee (Litchi chinensis) [18], rose (Rosa chinensis) [19], and carnation (Dianthus caryophyllus) [20] (Figure 2). As the mechanism underlying the positive effects of $\mathrm{H}_{2}$ on horticultural crops is progressively being revealed, the values of the application of $\mathrm{H}_{2}$ in horticulture are being increasingly realized.

The objective of this review is to evaluate the feasibility of $\mathrm{H}_{2}$ application in horticulture and the strategies of $\mathrm{H}_{2}$ application in horticultural crops, including $\mathrm{H}_{2}$ delivery methods, treatment stages, and $\mathrm{H}_{2}$ concentration applied. A discussion of the effects of $\mathrm{H}_{2}$ and its possible mechanisms will also be included. Together, the application of $\mathrm{H}_{2}$ may provide novel opportunities for improving horticultural production.

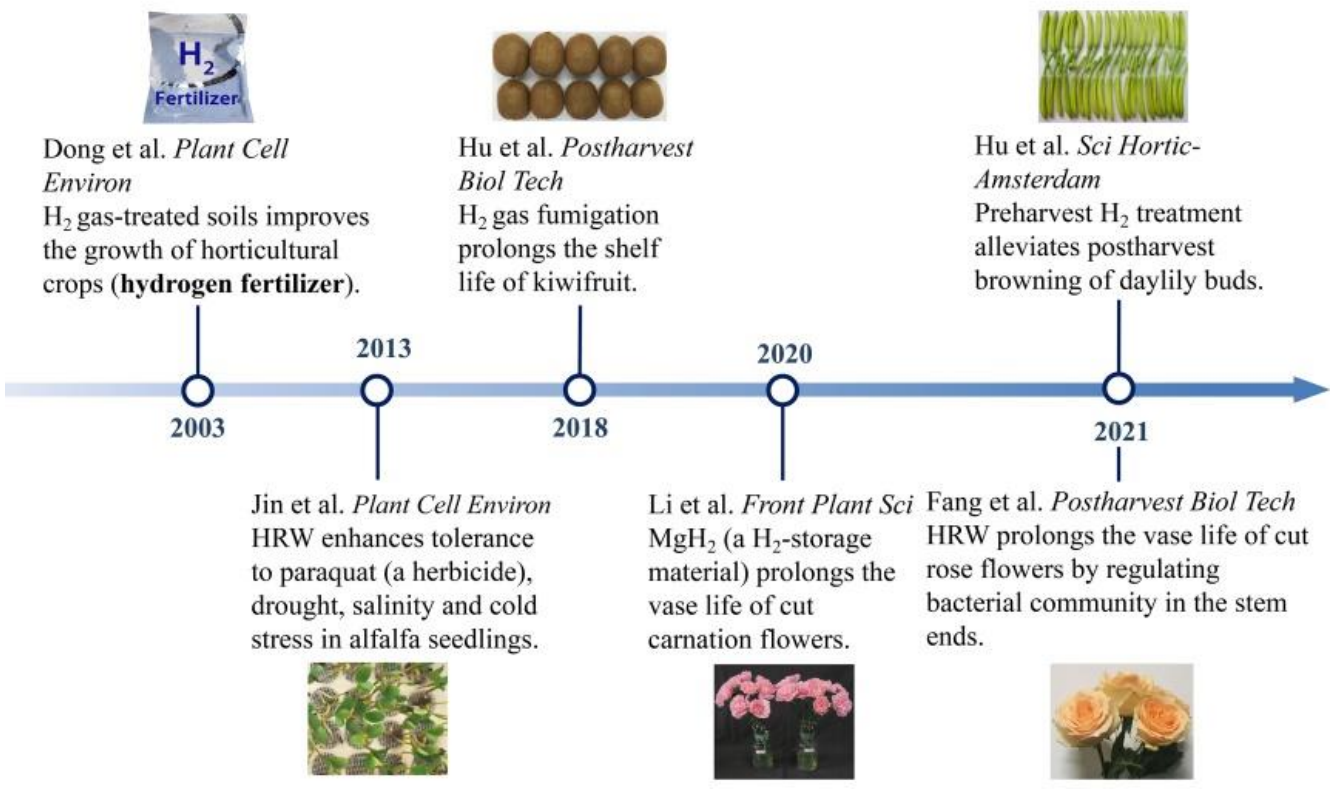

Figure 1. The developing profiles of the application of $\mathrm{H}_{2}$ in horticulture. 


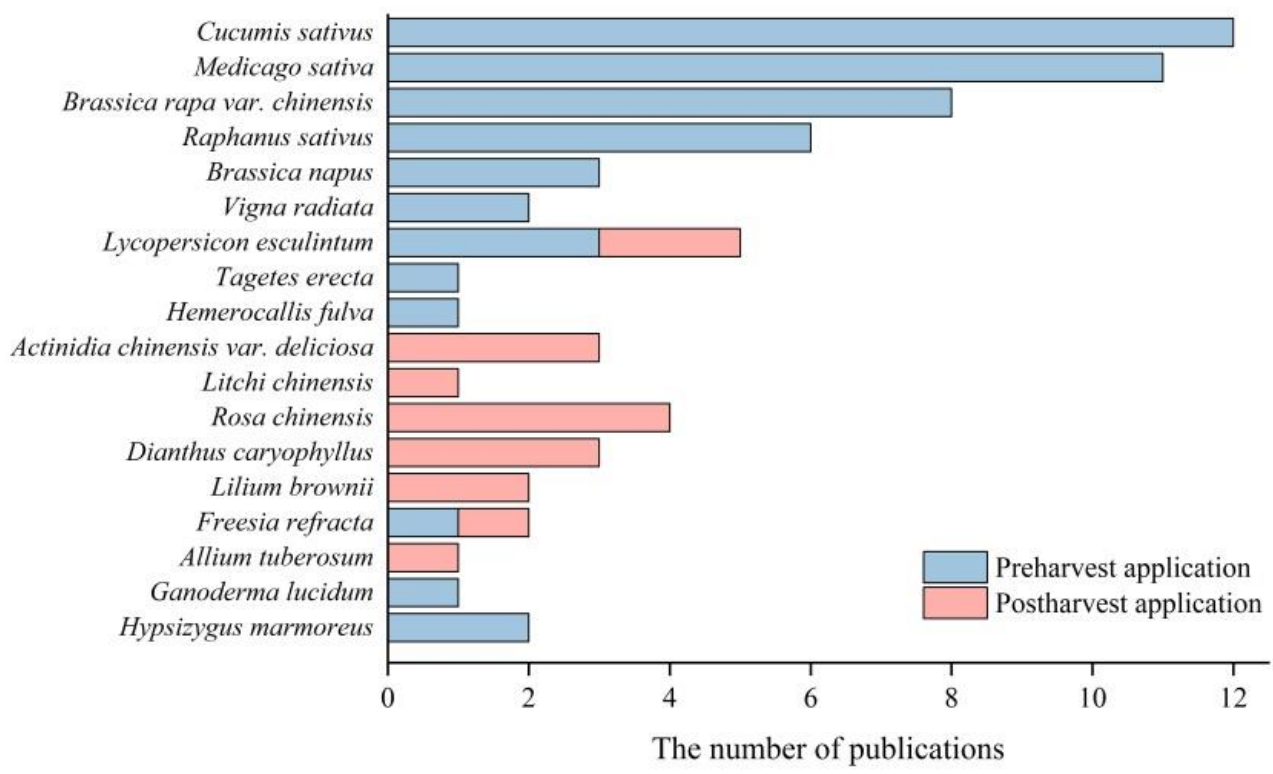

Figure 2. The species of the publications studied on the application of $\mathrm{H}_{2}$ in horticulture.

\section{Strategies of $\mathbf{H}_{\mathbf{2}}$ Application in Horticultural Crops}

\subsection{The Methods for $\mathrm{H}_{2}$ Delivery in Horticulture}

$\mathrm{H}_{2}$ is a flammable gas; thus, care needs to be taken with its handling and application. In early studies, the $\mathrm{H}_{2}$ treatment of soil was complicated, and soils are repeatedly exposed to $\mathrm{H}_{2}$ gas before planting [10]. Although $\mathrm{H}_{2}$ applied in gas form is not practical in the field, it is possible to use it under controlled airtight conditions. Previous studies observed that a $3 \mathrm{vol} \%$ or lower concentration of $\mathrm{H}_{2}$ was below the lower flammability limit of $\mathrm{H}_{2}$ (4 vol\%), but the modified atmosphere can prolong the shelf life of Chinese chive (Allium tuberosum) [21] or kiwifruit [22] stored at $4{ }^{\circ} \mathrm{C}$ or room temperature. Surprisingly, under pure $\mathrm{H}_{2}$ atmosphere, grapes did not show obvious signs of decay during 90 days of storage [23]. However, it is not practical to apply $\mathrm{H}_{2}$ in such a high concentration. Safety measures for handling $\mathrm{H}_{2}$ are necessary and important, but they can be learned from the use of $\mathrm{H}_{2}$ in the hydrogen energy industry.

The major method of $\mathrm{H}_{2}$ delivery is dispersion in water. Such a delivery method is very convenient for horticultural crops that are watered and fertilized by micro-irrigation. $\mathrm{H}_{2}$ produced from water electrolysis or released from a $\mathrm{H}_{2}$ gas cylinder is infused into water or nutrient solution. Subsequently, $\mathrm{H}_{2}$ enriched water/nutrient solution is diluted into required concentrations. The saturation concentration of $\mathrm{H}_{2}$ in water at room temperature and $1 \mathrm{~atm}$ was $\sim 800 \mu \mathrm{M}$ [24]; thus, the use of $\mathrm{H}_{2}$ in liquid form is relatively safe, easy, and effective for soil and plant treatments, especially in the field. Hydrogen-rich water (HRW) can be used for soaking seeds and fruits, spraying leaves, and irrigating soil, as well as additions to hydroponic solutions.

Since $\mathrm{H}_{2}$ naturally evolves from liquid, the residence time of $\mathrm{H}_{2}$ in $\mathrm{HRW}$ is $\sim 12 \mathrm{~h}$ [25], and HRW is commonly replaced every $12 / 24 \mathrm{~h}[14,19]$. In order to improve the concentration and residence time of $\mathrm{H}_{2}$ in liquid, nanobubble technology and solid $\mathrm{H}_{2}$-storage materials were developed as alterative HRW preparation choices.

$\mathrm{H}_{2}$ nanobubbles were produced by infusing $\mathrm{H}_{2}$ into liquid with a nanobubble aerator. The nanobubbles with properties of high internal pressure and negatively charged surface can increase the effective concentration and residence time of $\mathrm{H}_{2}$ in water [26]. Hydrogen nanobubble water was observed to exhibit improved efficacy compared to conventional HRW for prolonging the vase life of cut carnation flowers [26].

Solid $\mathrm{H}_{2}$-storage materials dissolved in liquid can supply sustainable $\mathrm{H}_{2}$. Magnesium hydride $\left(\mathrm{MgH}_{2}\right)$ is a promising and widely available $\mathrm{H}_{2}$-releasing material $[27,28]$. It has been found that the effect of $\mathrm{MgH}_{2}$ combined with citrate buffer solution on prolonging 
the vase life of cut carnation flowers was better than that of HRW, thus indicating its potential application value in horticulture [25] (Figure 1). Another solid $\mathrm{H}_{2}$-storage material ammonia borane $(\mathrm{AB})$ also exhibited effects on enhancing rapeseed seedlings tolerance against drought, salinity, or cadmium (Cd) stresses [29]. Additionally, AB@hMSN, a $\mathrm{H}_{2-}$ releasing nanomaterial, not only significantly increased residence time of $\mathrm{H}_{2}$ in water by more than $3 \mathrm{~d}$ but also induced lateral rooting in radish, tomato, rice, Arabidopsis, cucumber, and rapeseed seedlings in various degrees [30]. However, the synthesis of $\mathrm{AB} @ \mathrm{hMSN}$ requires encapsulating $\mathrm{AB}$ into hollow mesoporous silica nanoparticles ( $\mathrm{hMSN}$ ), which is a complex and costly process, therefore making its use unpractical for widespread use, such as in horticulture. In addition, the potential environment cost of the release of by-products has to be considered when solid $\mathrm{H}_{2}$-storage materials are widely used.

\subsection{The Timing of Application and/or Growth Stages}

$\mathrm{H}_{2}$ was applied at the preharvest and postharvest stages of horticultural crops. At the preharvest stage, the use of HRW to soak seeds for several hours can promote the growth of mung bean shoots and roots [31] and improve the tolerance to heat [32] or chilling [33] of cucumber seedlings. Seedlings such as cucumber [34], tomato [35], and marigold (Tagetes erecta) [36] incubated in HRW for 2-7 d can induce root development (Figure 3). In addition, the $\mathrm{H}_{2}$ treatment was effective in alleviating abiotic stresses including drought [34], salinity [29], UV-A [37], and osmotic stresses [38] or metal exposure [39-41] either before or under stressors or after the removal of these stressors. HRW added in media for mycelium culture of edible fungus, such as Ganoderma lucidum [42] and Hypsizygus marmoreus [43], and can also alleviate the toxicities of different stresses (including acetic acid (HAc), salinity, and heavy metals).

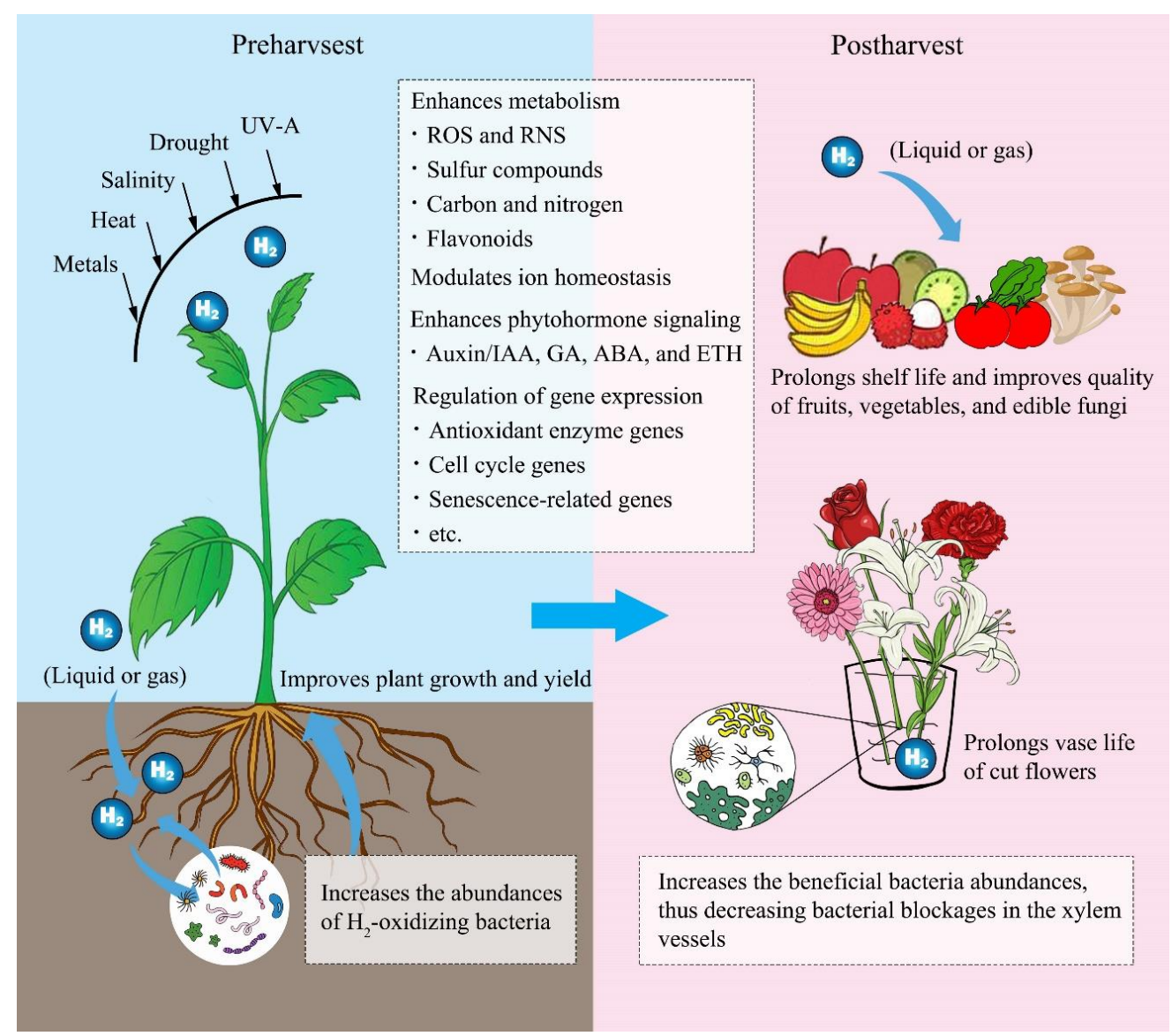

Figure 3. The physiological effects and possible mechanisms of $\mathrm{H}_{2}$ applied in horticulture. ROS, reactive oxygen species; RNS, reactive nitrogen species; IAA, indolylacetic acid; GA, gibberellin; ABA, abscisic acid; ETH, ethylene. 
Soil cultivation, spraying and irrigating with HRW at several growth stages, such as seedling, growing, and blooming period [44,45], or exposure to $\mathrm{H}_{2}$ gas before planting [10] can improve the growth of plants and promote early flowering. In addition, irrigation of HRW at the stages of bolting, growing, and the day prior to the period of harvest not only increased the yield of daylily buds but also reduced chilling injury and browning at storage, thus maintaining postharvest quality and prolonging shelf life of daylily buds [16]. These findings provide an important practical reference for horticultural production (Figure 1). Similarly, mycelial cultures treated with HRW increased the postharvest quality of $H$. marmoreus [46].

Moreover, postharvest $\mathrm{H}_{2}$ treatment can be beneficial for the preservation of horticultural products. Pretreatment with HRW by soaking fruits (such as kiwifruit [17], tomato [47], and lychee [18] as well as fresh-cut kiwifruit [48]) for less than 30 min can significantly maintain storage quality and prolong shelf life. $\mathrm{H}_{2}$ fumigation for pretreatment or throughout storage period can achieve similar effects in kiwifruit [22] (Figure 1) and Chinese chive [21].

HRW as a vase solution also delayed senescence and prolonged the vase life of cut flowers, such as rose [49], lily [50], carnation [25], freesia (Freesia refracta) [51], and lisianthus (Eustoma grandiflorum) [52]. However, an effective form of $\mathrm{H}_{2}$ has not yet been investigated for the preservation of cut flowers, which is a key concern due to the typical requirement of cut flower transportation. Perhaps the application of the solid $\mathrm{MgH}_{2}$ or $\mathrm{AB} @ \mathrm{hMSN} \mathrm{H}_{2}$ materials may be a solution to this problem.

\subsection{The Effective Concentration Range of $\mathrm{H}_{2}$ Treatment}

The range of $\mathrm{H}_{2}$ concentration is closely associated with the safety and efficacy of $\mathrm{H}_{2}$. Due to different $\mathrm{H}_{2}$ production properties of $\mathrm{H}_{2}$ generators, the concentration of $\mathrm{H}_{2}$ in fresh HRW (generally regarded as $100 \%$ saturation) was commonly around 220 860 $\mu \mathrm{M}[34,41,53]$. A high concentration of $\mathrm{H}_{2}$ might showed reduced benefits in certain plants $[15,26,42,46]$. The optimum concentration of HRW is associated with the species and varieties of plants and different treatment periods. For example, the treatment of $\sim 400 \mu \mathrm{M} \mathrm{H}_{2}$ in 4-day-old seedlings of pak choi 'Dongfang 2' reduced the toxicity of $\mathrm{Cd}$ [54] and $\mathrm{Ca}\left(\mathrm{NO}_{3}\right)_{2}$ stresses [44], while in 3-day-old pak choi 'Wuqing No. 1', $78 \mu \mathrm{M}$ $\mathrm{H}_{2}$ significantly induced lateral root formation [13]. In addition, lower concentrations of $\mathrm{H}_{2}$, such as $\sim 4.7 \mu \mathrm{M} \mathrm{H}_{2}$ or $\sim 45 \mu \mathrm{M} \mathrm{H}_{2}$, can significantly prolong the vase life of the cut rose 'Movie star' [55] or lily 'Manissa' [19] flowers, respectively, suggesting that cut flowers might be more sensitive to $\mathrm{H}_{2}$.

Carbon dioxide $\left(\mathrm{CO}_{2}\right)$ and nitrogen $\left(\mathrm{N}_{2}\right)$ are most often used in modified atmospheres for reducing respiration, thus delaying ripening and senescence of fruits and vegetables during storage [56]. Among horticultural products, the gas atmosphere of package usually consists of a lowered level of oxygen $\left(\mathrm{O}_{2} ; 1-10 \%\right)$, a heightened level of $\mathrm{CO}_{2}(0-20 \%)$, and $\mathrm{N}_{2}$ (70-99\%) [56]. In addition, 1-methylcyclopropene (1-MCP), an inhibitor of ethylene perception, has been used to extend the commercial life of fruits [57]. However, high levels of $\mathrm{CO}_{2}$ and low level of $\mathrm{O}_{2}$ may have a negative influence on the sensorial properties or uniform ripeness of some vegetables and fruits [56]. 1-MCP has also been observed to decrease the contents of sugars and volatiles $[57,58]$.

Recent studies have been observed that $\mathrm{H}_{2}$-modified atmosphere can also prolong the shelf life of vegetables and fruits. For example, a $\sim 1.2 \times 10^{3} \mu \mathrm{M} \mathrm{H}_{2}$ fumigation can maintain the postharvest quality of Chinese chive at $4{ }^{\circ} \mathrm{C}$ [21]. In kiwifruit, the positive effect of $\sim 0.2 \mu \mathrm{M} \mathrm{H}_{2}$ gas on prolonging shelf life was similar with that of 1-MCP $(0.04 \mu \mathrm{M})$ [22] However, high levels of $\mathrm{H}_{2}(\sim 1.8 \mu \mathrm{M})$ did not show obvious benefits compared to air control. Moreover, pure $\mathrm{H}_{2}$ atmosphere can prolong the storage life of grapes up to 90 days while in $\mathrm{N}_{2}$-atmosphere and air-atmosphere, the grapes have been blackened or are rotten [23]. The effectiveness and the effective concentration of $\mathrm{H}_{2}$ might vary substantially from species to species, and this needs further investigation. 
Accordingly, these observations reflect the complexity of the mechanisms underlying $\mathrm{H}_{2}$ functions in horticultural crops.

\section{3. $\mathrm{H}_{2}$ Exhibits Botanical Functions by Influencing Microorganisms}

Some of rhizospheric microbes can promote plant growth, such as increasing nutrient uptake and availability, stimulation of root growth, rhizoremediation, and plant stress control, resulting in improving productivity, and they are generally considered as plantgrowth promoting rhizobacteria (PGPR) [59]. Naturally $\mathrm{H}_{2}$ can typically be produced as a byproduct of $\mathrm{N}_{2}$ fixation by nitrogen-fixing microbes and is consumed by the soil $\mathrm{H}_{2}$-oxidizing bacteria [60]. Various $\mathrm{H}_{2}$-oxidizing bacteria are also known PGPR [61]. Previous studies reported that $\mathrm{H}_{2}$-treated soil promoted the plant's growth [10], attributing to bacteria in rhizosphere rather than fungi $[62,63]$. The analysis of terminal restriction fragment (TRF) profiles of $\mathrm{H}_{2}$-exposed soil samples indicated that the metabolism of $\mathrm{H}_{2}$ by $\mathrm{H}_{2}$-oxidizing bacteria was responsible for the variation in the microbial community structure of the soil [64]. Among $\mathrm{H}_{2}$-oxidizing bacteria, Variovorax paradoxus, Flavobacterium johnsoniae, and Burkholderia spp. were found in $\mathrm{H}_{2}$-treated soil to exert promotion effects on plant root elongation [61]. Thus, plant roots may be greatly benefited from $\mathrm{H}_{2}$-rich soil.

$\mathrm{H}_{2}$ can increase $\mathrm{CO}_{2}$ fixation in soil, thus promoting soil carbon deposition [60], which may be associated with bacterial RuBisCo activity of the soil [65]. In addition, it has been observed to increase the contents of soil enzymes (including dehydrogenase, catalase, urease, and invertase) in $\mathrm{H}_{2}$-treated soil [66]. Thereby, $\mathrm{H}_{2}$ may improve soil fertility by inducing PGPR metabolic activities.

Harvested fruits and vegetables are readily decayed by spoilage and pathogenic microorganisms. Botrytis cinerea causes gray mold disease in tomatoes [67]. It has been found that a 30-minute soak in HRW $\left(125 \mu \mathrm{M} \mathrm{H}_{2}\right)$ can reduce gray mold disease injury and lesion areas of inoculated tomato fruit, which might be attributed to $\mathrm{H}_{2}$-increasing polyphenol oxidase (PPO) activities and nitric oxide (NO) content [68]. Similarly, $\mathrm{H}_{2}$ fumigation $\left(\sim 0.2 \mu \mathrm{M} \mathrm{H}_{2}\right)$ also decreased visible decay symptoms in kiwifruit by inhibiting the progress of Phomopsis in vivo rather than in vitro [22]. These results indicated that $\mathrm{H}_{2}$ can boost natural plant immunity against pathogen infection. Moreover, it has been observed that HRW reduced the total colony number in fresh-cut kiwifruit [48]. The latest study found that HRW can significantly inhibit bacterial colonization and biofilm formation in the xylem vessels of cut rose flowers and increase water uptake by alleviating vascular occlusion [55] (Figure 1). Furthermore, HRW regulated the bacterial community, while the dominant bacteria Pseudomonas fluorescens and Brevundimonas diminuta promoted the vase life of cut rose flowers. This finding confirms the involvement of $\mathrm{H}_{2}$ in plant-microbe interactions. However, the identification of a specific mechanism is still lacking.

Notably, the ecological effects of $\mathrm{H}_{2}$ should be seriously considered, especially the impact for long-term use of $\mathrm{H}_{2}$ on soil ecosystems due to $\mathrm{H}_{2}$-modification of the microbial community structure.

\section{Possible Mechanisms Underlying $\mathrm{H}_{2}$ Responses in Horticultural Crops}

4.1. Involved in Reactive Oxygen Species (ROS) and Reactive Nitrogen Species (RNS) Metabolism

Reactive oxygen species (ROS) and reactive nitrogen species (RNS) are commonly involved in plants responses to various stresses [69]. For example, chilling [33], osmatic [38,70], paraquat stresses [11], and metal exposure [41,53,71] can induce ROS (including superoxide anions $\left(\mathrm{O}_{2}{ }^{-}\right)$, hydrogen peroxide $\left(\mathrm{H}_{2} \mathrm{O}_{2}\right)$, hydroxyl radical (.OH), etc.) and RNS (nitric oxide (NO), peroxynitrite $\left(\mathrm{ONOO}^{-}\right)$, etc.), disturbing the delicate redox homeostasis and causing cellular damage inside the plant cells. In postharvest fruits, vegetables, and cut flowers, ROS overproduction accelerated senescence process [16-18,21,52]. Additionally, ROS and RNS are vital signaling transducers in plant signaling networks for stress and development [72]. Therefore, the metabolic regulation of ROS and RNS is crucial for stress responses, growth, and development in plants. 
Endogenous $\mathrm{H}_{2}$ could be produced under abiotic stresses and senescence conditions in plants $[11,32,34,52] . \mathrm{H}_{2}$ can increase the activities of antioxidant enzymes such as superoxide dismutase (SOD), catalase (CAT), guaiacol peroxidase (POD), and ascorbate peroxidase (APX) and the transcript levels of corresponding genes, thus resulting in scavenging overproduced ROS and reestablishing redox homeostasis in alfalfa seedlings subjected to osmotic stress [11,70] (Table 1). The similar HRW responses were also observed in cut rose flowers [19] and H. marmoreus during storage [46]. Moreover, $\mathrm{H}_{2}$ was observed to maintain the redox balance by increasing the contents of ascorbic acid (AsA) [40], glutathione (GSH) [15], total phenols [18], and anthocyanin [37]. Therefore, it is possible that $\mathrm{H}_{2}$ has indirect effects on antioxidant capacity.

Table 1. Role of $\mathrm{H}_{2}$ involved in reactive oxygen species (ROS) and reactive nitrogen species (RNS) metabolism in horticultural crops.

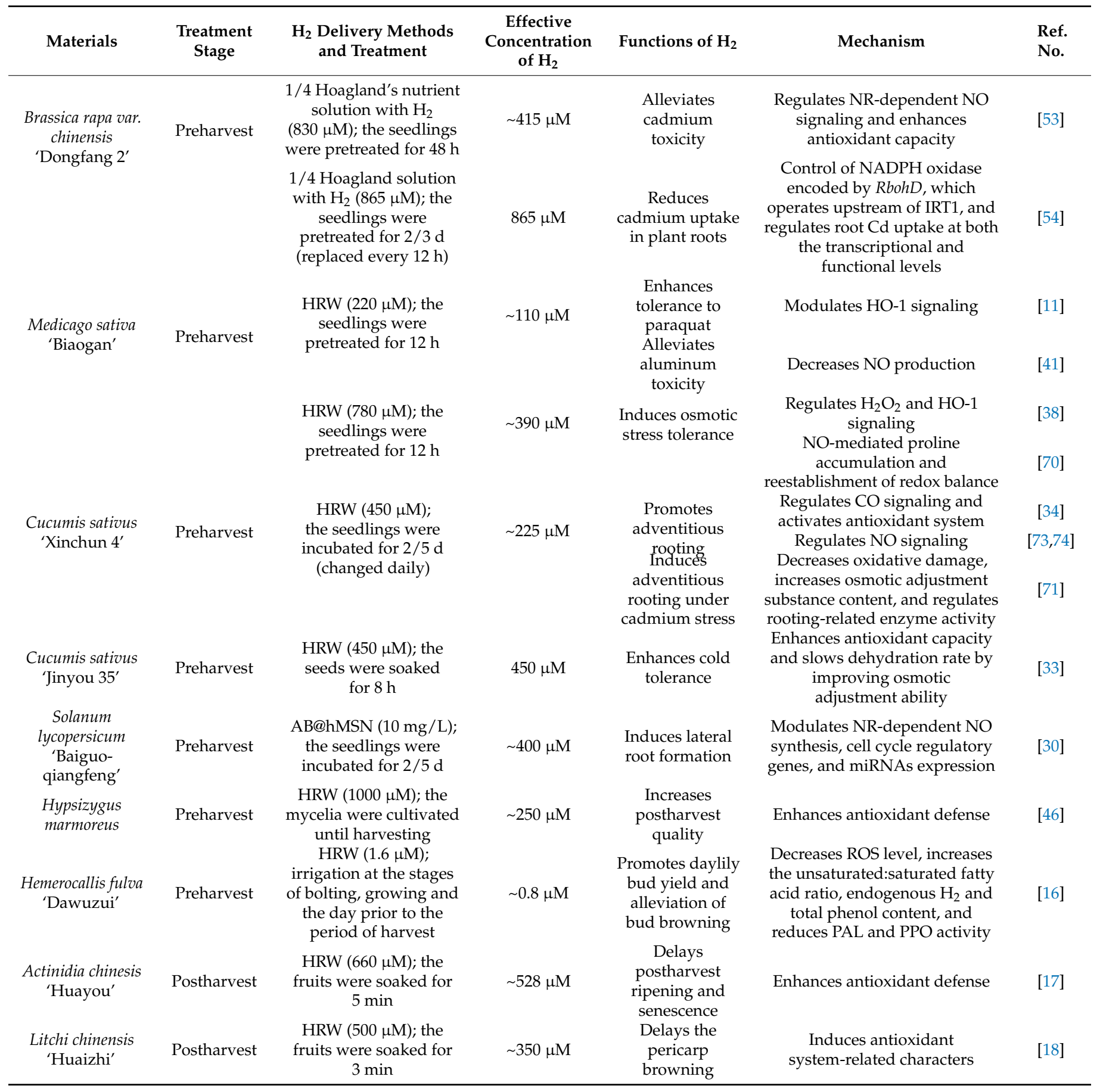


Table 1. Cont.

\begin{tabular}{|c|c|c|c|c|c|c|}
\hline Materials & $\begin{array}{l}\text { Treatment } \\
\text { Stage }\end{array}$ & $\begin{array}{l}\mathrm{H}_{2} \text { Delivery Methods } \\
\text { and Treatment }\end{array}$ & $\begin{array}{c}\text { Effective } \\
\text { Concentration } \\
\text { of } \mathrm{H}_{2}\end{array}$ & Functions of $\mathbf{H}_{2}$ & Mechanism & $\begin{array}{l}\text { Ref. } \\
\text { No. }\end{array}$ \\
\hline $\begin{array}{l}\text { Rosa chinensis } \\
\text { 'Kardinal'; Lilium } \\
\text { brownii 'Manissa' }\end{array}$ & Postharvest & $\begin{array}{l}\text { HRW }(450 \mu \mathrm{M}) \text {; cut } \\
\text { flowers were incubated } \\
\text { for vase period } \\
\text { (changed daily) }\end{array}$ & $\begin{array}{c}\sim 225 \mu \mathrm{M} \\
\text { (Rose); } \\
\sim 45 \mu \mathrm{M} \text { (Lily) }\end{array}$ & $\begin{array}{l}\text { Improves the } \\
\text { vase life and } \\
\text { quality }\end{array}$ & $\begin{array}{l}\text { Maintains water balance and } \\
\text { membrane stability by reducing } \\
\text { stomatal size and oxidative } \\
\text { damage }\end{array}$ & [19] \\
\hline Allium tuberosum & Postharvest & $\begin{array}{l}\text { Gas; the leaves were } \\
\text { fumigated for storage } \\
\text { period (renewed daily) }\end{array}$ & $\sim 1.2 \times 10^{3} \mu \mathrm{M}$ & $\begin{array}{c}\text { Prolongs the } \\
\text { shelf life and } \\
\text { maintain storage } \\
\text { quality }\end{array}$ & Increases antioxidant capacity & [21] \\
\hline $\begin{array}{c}\text { Dianthus } \\
\text { caryophyllus } \\
\text { 'Pink Diamond' }\end{array}$ & Postharvest & $\begin{array}{l}\text { HNW }(\sim 500 \mu \mathrm{M}) \text {; cut } \\
\text { flowers were incubated } \\
\text { for } 3 \mathrm{~d} \text { (changed daily) }\end{array}$ & $\sim 50 \mu \mathrm{M}$ & $\begin{array}{l}\text { Prolongs the } \\
\text { vase life }\end{array}$ & $\begin{array}{l}\text { Reduces ROS accumulation and } \\
\text { senescence-associated enzyme } \\
\text { activities }\end{array}$ & [26] \\
\hline $\begin{array}{l}\text { Rosa chinensis } \\
\text { 'Carola' }\end{array}$ & Postharvest & $\begin{array}{l}\mathrm{MgH}_{2}(0.001 \mathrm{~g} / \mathrm{L}) \text {; cut } \\
\text { flowers were incubated } \\
\text { for vase periods } \\
\text { (changed daily) }\end{array}$ & Not shown & $\begin{array}{l}\text { Prolongs the } \\
\text { vase life }\end{array}$ & $\begin{array}{l}\text { Maintains ROS balance by } \\
\text { modulating NO synthesis }\end{array}$ & [28] \\
\hline $\begin{array}{l}\text { Lilium brownii } \\
\text { 'Manissa' }\end{array}$ & Postharvest & $\begin{array}{l}\text { HRW; cut flowers were } \\
\text { incubated for vase } \\
\text { period (changed daily) }\end{array}$ & $\begin{array}{c}\text { Not shown } \\
(1 \% \text { saturation } \\
\text { HRW })\end{array}$ & $\begin{array}{l}\text { Prolongs the } \\
\text { vase life }\end{array}$ & $\begin{array}{l}\text { Regulates NO signaling and } \\
\text { regulates the expression of the } \\
\text { photosynthesis-related AtpA }\end{array}$ & [50] \\
\hline $\begin{array}{l}\text { Freesia refracta } \\
\text { 'Red passion' }\end{array}$ & Postharvest & $\begin{array}{l}\text { HRW }(75 \mu \mathrm{M}) \text {; cut } \\
\text { flowers were pretreated } \\
\text { for } 12 \mathrm{~h}\end{array}$ & $\sim 0.75 \mu \mathrm{M}$ & $\begin{array}{l}\text { Prolongs the } \\
\text { vase life }\end{array}$ & Improves antioxidant capacity & [51] \\
\hline $\begin{array}{l}\text { Eustoma } \\
\text { grandiflorum }\end{array}$ & Postharvest & $\begin{array}{l}\text { HRW }(780 \mu \mathrm{M}) \text {; cut } \\
\text { flowers were incubated } \\
\text { for vase period } \\
\text { (changed daily) }\end{array}$ & $\sim 78 \mu \mathrm{M}$ & $\begin{array}{l}\text { Prolongs the } \\
\text { vase life }\end{array}$ & Maintains redox homeostasis & [52] \\
\hline
\end{tabular}

Moreover, $\mathrm{H}_{2}$ can modulate $\mathrm{H}_{2} \mathrm{O}_{2}$ signaling by respiratory burst oxidase homolog $\mathrm{D}(\mathrm{RbohD})$, mediated by $\mathrm{Ca}^{2+}$ signaling, which resulted in a decrease in $\mathrm{Cd}$ uptake in the roots of pak choi seedlings [57]. $\mathrm{H}_{2} \mathrm{O}_{2}$ also plays a vital role in $\mathrm{H}_{2}$-triggered osmotic tolerance via heme oxygenase-1 (HO-1) signaling in alfalfa [38].

$\mathrm{NO}$ as a downstream signal molecule was involved in $\mathrm{H}_{2}$-enhanced tolerance to osmosis [70], the fungal pathogen [68], and $\mathrm{H}_{2}$-promoted root development [73,74], as well as prolonging the vase life of cut flowers $[28,50]$ (Table 1$). \mathrm{H}_{2}$ can induce NO synthesis mainly by nitrate reductase (NR), thus activating the antioxidant enzymatic system $[28,53]$. AB@hMSN-mediated $\mathrm{H}_{2}$ supply also induced lateral root formation in tomato by regulating the transcription levels of cell cycle regulatory genes, miR160, and miR390a via $\mathrm{NR}$-dependent $\mathrm{NO}$ [30]. However, there is no evidence of direct interactions among $\mathrm{H}_{2}$, ROS, and RNS in plants. The role of $\mathrm{H}_{2}$ in ROS and RNS signaling networks needs to be a focus for further research.

\subsection{Modulation in Sulfur Compounds' Metabolism}

Sulfur assimilation, cysteine and methionine metabolism, and GSH metabolism eventually influence plant growth, development, and stress responses [75]. For example, under Cd stress, HRW upregulated the genes involved in sulfate absorption, transport, and sulfur assimilation (including ATP sulfurylases, $5^{\prime}$-adenylylsulfate reductases, O-acetylserine(thiol)lyase, glutathione S-transferase (GST), cysteine desulfurases, etc.), thus increasing sulfur contents of both leaves and roots in alfalfa [76,77] (Table 2). GSH content and GSH/GSSG ratio increased after HRW pretreatment by increasing the transcripts of glutathione synthase (GS) and glutathione reductase (GR) [15,39,40], as well as phytochelatins (PCs) content [76], thus associating with Cd chelation and antioxidant capacity in pak choi. Subsequently, $\mathrm{H}_{2}$ was observed to increase transcript levels of SlGSH1 and SlGSH2 that encode $\gamma$-glutamylcysteine synthetase ( $\gamma$-ECS) and GS, confirming the stimulation of GSH synthesis and, thus, resulting in inducing lateral root branching of tomato [35]. 
Table 2. Role of $\mathrm{H}_{2}$ involved in sulfur compounds metabolism in horticultural crops.

\begin{tabular}{|c|c|c|c|c|c|c|}
\hline Materials & $\begin{array}{l}\text { Treatment } \\
\text { Stage }\end{array}$ & $\begin{array}{c}\mathrm{H}_{2} \text { Delivery Methods } \\
\text { and Treatment }\end{array}$ & $\begin{array}{c}\text { Effective } \\
\text { Concentration } \\
\text { of } \mathrm{H}_{2}\end{array}$ & Functions of $\mathbf{H}_{2}$ & Mechanism & $\begin{array}{l}\text { Ref } \\
\text { No. }\end{array}$ \\
\hline $\begin{array}{l}\text { Brassica rapa var. } \\
\text { chinensis } \\
\text { 'Dongfang 2' }\end{array}$ & Preharvest & $\begin{array}{l}\text { 1/4 Hoagland's nutrient } \\
\text { solution with } \mathrm{H}_{2} ; \text { the } \\
\text { seedlings were } \\
\text { incubated for } 48 \mathrm{~h} \\
\text { (replaced every } 12 \mathrm{~h} \text { ) } \\
\text { after removing } \\
\text { cadmium stress }\end{array}$ & $\begin{array}{l}\text { Not shown } \\
\quad(50 \% \\
\text { saturation } \\
\text { HRW })\end{array}$ & $\begin{array}{l}\text { Enhances } \\
\text { cadmium } \\
\text { tolerance }\end{array}$ & $\begin{array}{c}\text { Reestablishes reduced GSH } \\
\text { homeostasis }\end{array}$ & [39] \\
\hline \multirow[t]{3}{*}{$\begin{array}{l}\text { Medicago sativa } \\
\text { 'Victoria' }\end{array}$} & Preharvest & $\begin{array}{l}\text { HRW }(220 \mu \mathrm{M}) \text {; the } \\
\text { seedlings were } \\
\text { pretreated for } 12 \mathrm{~h}\end{array}$ & $\sim 22 \mu \mathrm{M}$ & $\begin{array}{l}\text { Alleviates } \\
\text { cadmium } \\
\text { toxicity }\end{array}$ & $\begin{array}{l}\text { Reduces cadmium } \\
\text { accumulation and reestablishes } \\
\text { GSH homeostasis } \\
\text { Expression regulation of genes } \\
\text { relevant to sulfur and } \\
\text { glutathione metabolism, } \\
\text { resulting in enhanced } \\
\text { glutathione metabolism and } \\
\text { activating antioxidant defense } \\
\text { and cadmium chelation }\end{array}$ & [76] \\
\hline & & & & & $\begin{array}{l}\text { Decreases oxidative damage, } \\
\text { enhances sulfur compound } \\
\text { metabolic process, and } \\
\text { reestablishes nutrient element } \\
\text { homeostasis }\end{array}$ & [77] \\
\hline & & & & $\begin{array}{l}\text { Alleviates } \\
\text { mercury toxicity }\end{array}$ & $\begin{array}{l}\text { Reduces mercury accumulation } \\
\text { and reestablishes redox } \\
\text { homeostasis (GSH, AsA, and } \\
\text { antioxidant enzymes) }\end{array}$ & [40] \\
\hline $\begin{array}{l}\text { Solanum } \\
\text { lycopersicum } \\
\text { 'Baiguo- } \\
\text { qiangfeng' }\end{array}$ & Preharvest & $\begin{array}{l}\text { HRW }(780 \mu \mathrm{M}) \text {; the } \\
\text { seedlings were } \\
\text { incubated for } 4 \mathrm{~d} \\
\text { (changed daily) }\end{array}$ & $\sim 390 \mu \mathrm{M}$ & $\begin{array}{l}\text { Influences lateral } \\
\text { root branching }\end{array}$ & $\begin{array}{l}\text { Promotes } \gamma \text {-ECS-dependent } \\
\text { GSH production }\end{array}$ & [35] \\
\hline $\begin{array}{l}\text { Ganoderma } \\
\text { lucidum strain } \mathrm{HG}\end{array}$ & Preharvest & $\begin{array}{l}\text { HRW }(220 \mu \mathrm{M}) \text {; added } \\
\text { to the medium after } \\
4 \text { days of } \\
\text { mycelium culture. }\end{array}$ & $\sim 11 \mu \mathrm{M}$ & $\begin{array}{l}\text { Regulates } \\
\text { morphology, } \\
\text { growth, and } \\
\text { secondary } \\
\text { metabolism }\end{array}$ & $\begin{array}{l}\text { Increases glutathione } \\
\text { peroxidase activity under } \\
\text { HAc stress }\end{array}$ & [42] \\
\hline $\begin{array}{l}\text { Dianthus } \\
\text { caryophyllus 'Pink } \\
\text { Diamond' }\end{array}$ & Postharvest & $\begin{array}{c}\mathrm{MgH}_{2}\left(0.1 \mathrm{~g} / \mathrm{L} \mathrm{MgH}_{2}\right. \\
\text { and } 0.1 \mathrm{M} \text { PBS (pH 3.4); } \\
\text { cut flowers were } \\
\text { incubated for vase } \\
\text { period (changed daily) }\end{array}$ & $\sim 400 \mu \mathrm{M}$ & $\begin{array}{l}\text { Prolongs the } \\
\text { vase life }\end{array}$ & $\begin{array}{c}\mathrm{H}_{2} \mathrm{~S} \text {-mediated reestablishment } \\
\text { of redox homeostasis and } \\
\text { increased transcript levels of } \\
D c b G a l \text { and DcGST1 }\end{array}$ & [25] \\
\hline
\end{tabular}

Glutathione peroxidase (GPx) is an essential component of glutathione antioxidant system [78]. In G. lucidum, HAc caused ROS production and inhibited GPX activity [42]. However, HRW application could restore GPX activity and reestablish GSH homeostasis, thus reestablishing redox balance. It has been further found that HRW was unable to alleviate HAc-induced ROS overproduction and decreased biomass in GPX defective strain, while $g p x$ overexpression strains exerted tolerance to oxidative stress. Thus, it suggested that GPX might be a target gene of $\mathrm{H}_{2}$ signaling.

Hydrogen sulfide $\left(\mathrm{H}_{2} \mathrm{~S}\right)$, a component of cysteine metabolism, can act as a signal molecule involved in various physiological processes in plants, including the responses to abiotic stresses, seed germination, root organogenesis, fruit ripening, etc. [79]. The regulatory function of $\mathrm{H}_{2} \mathrm{~S}$ partly acts through protein post-translational modification and persulfidation [80]. Therefore, $\mathrm{H}_{2}$ and $\mathrm{H}_{2} \mathrm{~S}$ may share roles in the signaling pathway of plants, while the interaction between $\mathrm{H}_{2}$ and $\mathrm{H}_{2} \mathrm{~S}$ was also observed [25,81]. For example, $\mathrm{H}_{2}$ could enhance ${ }_{L}$-Cys desulfhydrase (DES)-dependent $\mathrm{H}_{2} \mathrm{~S}$ synthesis [81]. Genetic evidence further showed that $\mathrm{H}_{2} \mathrm{~S}$ acted as a downstream molecule of endogenous $\mathrm{H}_{2}$ control of stomatal closure and resulted in enhanced osmotic tolerance. A recent study also found that $\mathrm{H}_{2} \mathrm{~S}$ was involved in $\mathrm{MgH}_{2}$-prolonged vase life of cut carnation flowers via 
increasing GST expression [25]. However, whether or how $\mathrm{H}_{2}$ influences $\mathrm{H}_{2} \mathrm{~S}$-dependent persulfidation requires further investigation.

\subsection{Involvement in Flavonoids Metabolism}

In plants, flavonoids and their glycoconjugates (glycosides) have evolved to protect against ultraviolet radiation (UV)-triggered oxidative damage [82]. Xie et al. [83] found that under UV-B irradiation, HRW promoted alfalfa tolerance to UV-B stress, accompanied by enhancement of flavonoids profiles (included isoflavone, flavanone, flavonol, chalcone, and pterocarpan). HRW can increase transcript levels of flavonoids biosyntheticrelated genes, including $L_{-}$-phenylalanin ammonialyase $(P A L)$, chalcone synthase $(\mathrm{CHS})$, chalcone isomerase (CHI), flavonol synthase (FLS), isoflavone synthase (IFS), and isoflavone 6-O-methyl transferase (6IOMT) (Table 3).

Anthocyanins, one of the important flavonoids, are the main pigments responsible for the red and blue colors of fruits and flowers, playing a vital role in attracting pollinators and protecting plants from UV irradiation [84]. Moreover, anthocyanin-rich foods attract consumers due to their desirable colors and health-promoting value [85]. Under UV-A irradiation, cyanidin, the main anthocyanidin in the hypocotyls of radish sprouts, was strongly accumulated by HRW treatment [37]. However, the positive effect of $\mathrm{H}_{2}$ on anthocyanidins accumulation varied according to cultivars of radish. HRW intensified the transcript levels for anthocyanin biosynthesis-related genes, including $P A L, C H S$, flavanone 3-hydroxylase (F3H), dihydroflavonol 4-reductase (DFR), and anthocyanidin synthase (ANS). Moreover, inositol 1,4,5-trisphosphate ( $\mathrm{InsP}_{3}$ )-dependent calcium signaling pathways might play an important role in HRW-regulated anthocyanin biosynthesis under UV-A irradiation [86]. Transcriptome analysis further revealed that the MYB-bHLH-WD40 complex accounting for major transcription factors was involved in HRW-regulated anthocyanin biosynthesis in radish sprouts under UV-A irradiation [87]. In addition to UVA, HRW could also increase anthocyanidins contents under blue light [88].

Flavonoids are well known for their benefits in human health and are used in nutrition, pharmaceuticals, medicine, and cosmetics [89]. Therefore, HRW may provide a method to improve the quality of horticultural crops.

Table 3. Role of $\mathrm{H}_{2}$ involved in flavonoids metabolism in horticultural crops.

\begin{tabular}{|c|c|c|c|c|c|c|}
\hline Materials & $\begin{array}{l}\text { Treatment } \\
\text { Stage }\end{array}$ & $\begin{array}{c}\mathrm{H}_{2} \text { Delivery Methods } \\
\text { and Treatment }\end{array}$ & $\begin{array}{c}\text { Effective } \\
\text { Concentration of } \\
\mathrm{H}_{2}\end{array}$ & Functions of $\mathbf{H}_{2}$ & Mechanism & Ref. No. \\
\hline $\begin{array}{l}\text { Raphanus sativus } \\
\text { 'Qingtou'; } \\
\text { R. sativus } \\
\text { 'Yanghua' }\end{array}$ & Preharvest & $\begin{array}{c}\text { HRW }(220 \mu \mathrm{M}) ; \\
1 / 4 \text { Hoagland's nutrient } \\
\text { solution with } \mathrm{H}_{2} \\
\left(220 \mu \mathrm{M} \mathrm{H} \mathrm{H}_{2}\right) ; \text { the seeds } \\
\text { were soaked in HRW for } \\
12 \mathrm{~h} \text {; sprouts were } \\
\text { incubated in nutrient } \\
\text { solution with } \mathrm{H}_{2} \text { for } 3 \mathrm{~d} \\
\text { (replaced every } 12 \mathrm{~h} \text { ) } \\
\text { under UV-A }\end{array}$ & $\sim 220 \mu \mathrm{M}$ & $\begin{array}{c}\text { Regulates } \\
\text { anthocyanin } \\
\text { synthesis under } \\
\text { UV-A }\end{array}$ & $\begin{array}{c}\text { Reestablishes ROS } \\
\text { homeostasis and } \\
\text { regulates anthocyanin } \\
\text { biosynthesis-related gene } \\
\text { expression }\end{array}$ & [37] \\
\hline \multirow[t]{2}{*}{$\begin{array}{l}\text { Raphanus. } \\
\text { sativus 'Yanghua' }\end{array}$} & \multirow[t]{2}{*}{ Preharvest } & $\begin{array}{l}\text { HRW }(781 \mu \mathrm{M}) \text {; the } \\
\text { seedlings were incubated } \\
\text { for } 48 / 60 \mathrm{~h} \text { (replaced } \\
\text { every } 12 \mathrm{~h} \text { ) under UV-A }\end{array}$ & $\sim 781 \mu \mathrm{M}$ & $\begin{array}{l}\text { Promotes the } \\
\text { biosynthesis of } \\
\text { anthocyanin } \\
\text { under UV-A }\end{array}$ & $\begin{array}{c}\text { Regulates } \\
\text { InsP }_{3} \text {-dependent calcium } \\
\text { signaling } \\
\text { Involved in } \\
\text { phytohormones, MAPKs } \\
\text { and } \mathrm{Ca}^{2+} \text { signaling }\end{array}$ & [87] \\
\hline & & $\begin{array}{l}\text { HRW }(220 \mu \mathrm{M}) \text {; the } \\
\text { seedlings were incubated } \\
\text { for } 72 \mathrm{~h} \text { (replaced every } \\
12 \mathrm{~h} \text { ) under short } \\
\text { wavelength light }\end{array}$ & $\sim 220 \mu \mathrm{M}$ & $\begin{array}{c}\text { Promotes } \\
\text { anthocyanin } \\
\text { accumulation } \\
\text { under short } \\
\text { wavelength light }\end{array}$ & $\begin{array}{l}\text { Promotes activities and } \\
\text { transcription of } \\
\text { anthocyanin } \\
\text { biosynthesis-related } \\
\text { enzyme (including CHS } \\
\text { and UFGT) }\end{array}$ & [88] \\
\hline $\begin{array}{l}\text { Medicago sativa } \\
\text { 'Victoria' }\end{array}$ & Preharvest & $\begin{array}{l}\text { HRW }(781 \mu \mathrm{M}) ; \text { the } \\
\text { seedlings were } \\
\text { pretreated for } 12 \mathrm{~h}\end{array}$ & $\sim 390 \mu \mathrm{M}$ & $\begin{array}{c}\text { Alleviates } \\
\text { UV-B-triggered } \\
\text { oxidative damage }\end{array}$ & $\begin{array}{l}\text { Regulates (iso)flavonoids } \\
\text { metabolism and } \\
\text { antioxidant defense }\end{array}$ & [83] \\
\hline
\end{tabular}




\section{4. $\mathrm{H}_{2}$ Is Involved in Carbon and Nitrogen Metabolism}

A previous study has observed that endogenous $\mathrm{H}_{2}$ production can be inhibited by an inhibitor of photosynthetic electron flow, indicating that, in plants, endogenous $\mathrm{H}_{2}$ production may be associated with photosynthesis [52], and $\mathrm{H}_{2}$ could, in turn, have an impact on photosynthesis [32] (Table 4). It has been observed that $\mathrm{H}_{2}$ increased chlorophyll content, alleviated heat-induced damage to PSII, and effectively maintained higher photosynthetic capacity for cucumber seedlings subjected to heat stress [32]. $\mathrm{H}_{2}$ also mitigated photoinhibition caused by chilling stress [90]. The activities of the carbon metabolism-related enzymes, such as sucrose synthetase (SS) and sucrose phosphate synthetase (SPS), and nitrogen metabolism-related enzymes, such as reduced nitrate reductase (NR), glutamine synthetase (GS), glutamate synthase (GOGAT), and glutamate dehydrogenase (GDH), were obviously increased by HRW application, resulting in enhancements in the contents of total sugar, sucrose, total nitrogen, ammonia, and nitrate nitrogen in cucumber seedlings [90]. These results indicated that $\mathrm{H}_{2}$ can enhance plant tolerance relative to extreme temperature stress by increasing the accumulation of carbon and nitrogen compounds. Additionally, in H. marmoreus mycelia, HRW activated pyruvate kinase, in combination with its induced gene expression, suggesting that HRW might enhance glucose metabolism [43].

Table 4. Roles of $\mathrm{H}_{2}$ involved in carbon and nitrogen metabolism in horticultural crops.

\begin{tabular}{|c|c|c|c|c|c|c|}
\hline Materials & $\begin{array}{l}\text { Treatment } \\
\text { Stage }\end{array}$ & $\begin{array}{c}\mathrm{H}_{2} \text { Delivery Methods and } \\
\text { Treatment }\end{array}$ & $\begin{array}{c}\text { Effective } \\
\text { Concentration of } \\
\mathbf{H}_{2} \\
\end{array}$ & Functions of $\mathbf{H}_{2}$ & Mechanism & Ref. No. \\
\hline $\begin{array}{l}\text { Cucumis } \\
\text { sativus } \\
\text { 'Xinjinchun } \\
\text { No. } 4 \text { ' }\end{array}$ & Preharvest & $\begin{array}{l}\text { Hoagland's nutrient solution } \\
\text { with } \mathrm{H}_{2}\left(220 \mu \mathrm{M} \mathrm{H}_{2}\right) \text {; the } \\
\text { seedlings were pretreated for } \\
\quad 7 \mathrm{~d} \text { (replaced daily) }\end{array}$ & $\sim 110 \mu \mathrm{M}$ & $\begin{array}{l}\text { Improves heat } \\
\text { tolerance }\end{array}$ & $\begin{array}{c}\text { Improves } \\
\text { photosynthetic and } \\
\text { antioxidant and } \\
\text { increases HSP70 content }\end{array}$ & [32] \\
\hline $\begin{array}{l}\text { Brassica rapa } \\
\text { var. chinensis } \\
\text { 'Dongfang 2' }\end{array}$ & Preharvest & $\begin{array}{l}\text { HRW; } 1 / 4 \text { Hoagland's } \\
\text { nutrient solution with } \mathrm{H}_{2} \\
\left(835.1 \mu \mathrm{M} \mathrm{H}_{2}\right) \text {; regarding soil } \\
\text { cultivation, sprays with HRW } \\
(50 \mathrm{~mL}) \text { at every } 12 \mathrm{~h} \text { for } 17 \mathrm{~d} \text {; } \\
\text { for hydroponic solutions, the } \\
\text { seedlings were incubated in } \\
1 / 4 \text { Hoagland solution with } \\
\mathrm{H}_{2} \text { for } 4 \mathrm{~d} \text { (replaced every } \\
12 \mathrm{~h} \text { ) with } \mathrm{Ca}\left(\mathrm{NO}_{3}\right)_{2}\end{array}$ & $\sim 417 \mu \mathrm{M}$ & $\begin{array}{c}\text { Reduces } \\
\mathrm{Ca}\left(\mathrm{NO}_{3}\right)_{2} \text { toxicity } \\
\text { and improves the } \\
\text { growth of } \\
\text { seedlings }\end{array}$ & $\begin{array}{l}\text { Enhances antioxidant } \\
\text { capacities and } \\
\text { reestablishes nitrate } \\
\text { homeostasis }\end{array}$ & [44] \\
\hline $\begin{array}{l}\text { Cucumis } \\
\text { sativus } \\
\text { 'Jinyou } 35^{\prime}\end{array}$ & Preharvest & $\begin{array}{l}\text { HRW }(450 \mu \mathrm{M}) \text {; the seeds } \\
\text { were soaked for } 8 \mathrm{~h}\end{array}$ & $\sim 450 \mu \mathrm{M}$ & $\begin{array}{l}\text { Enhances lower } \\
\text { temperature } \\
\text { tolerance }\end{array}$ & $\begin{array}{l}\text { Increases the activities } \\
\text { of key photosynthetic } \\
\text { enzymes and maintains } \\
\text { a high level of carbon } \\
\text { and nitrogen } \\
\text { metabolism }\end{array}$ & [90] \\
\hline $\begin{array}{l}\text { Hypsizygus } \\
\text { marmoreus }\end{array}$ & Preharvest & $\begin{array}{l}\text { HRW }(800 \mu \mathrm{M}) \text {; mycelia were } \\
\text { incubated for } 5 \mathrm{~d} \text { (replaced } \\
\text { every } 12 \mathrm{~h} \text { ) after removal of } \\
\text { cadmium stress }\end{array}$ & $\sim 800 \mu \mathrm{M}$ & $\begin{array}{c}\text { Alleviates salinity } \\
\text { and heavy metal } \\
\text { toxicity }\end{array}$ & $\begin{array}{l}\text { Activates pyruvate } \\
\text { kinase, along with its } \\
\text { induced gene } \\
\text { expression }\end{array}$ & [43] \\
\hline $\begin{array}{c}\text { Solanum } \\
\text { lycopersicum } \\
\text { 'Jiafen No. 2' }\end{array}$ & Postharvest & $\begin{array}{l}\text { HRW }(780 \mu \mathrm{M}) \text {; the fruits } \\
\text { were soaked for } 20 \text { min }\end{array}$ & $\sim 585 \mu \mathrm{M}$ & $\begin{array}{l}\text { Reduces nitrite } \\
\text { accumulation } \\
\text { during storage }\end{array}$ & $\begin{array}{l}\text { Inhibits / increases the } \\
\text { activity and transcript } \\
\text { level of NR/NiR }\end{array}$ & [47] \\
\hline
\end{tabular}

The overuse of nitrogen fertilizer can cause severe secondary salinization and decrease yield in horticultural crops [91]. Vegetables are the main source of nitrate intake into the human body. With bacterial activity, excessive nitrate is converted to nitrite, which is considered as an important human dietary carcinogenic factor [92]. Thus, the accumulations of nitrate and nitrite are increasingly closely monitored. A recent study has shown that nitrate content in pak choi could be reduced by HRW treatment through enhancing the activities of NR and GS [44]. Moreover, HRW regulated the transcripts of long-distance transporters (BcNRT1.5 and BcNRT1.8) to reduce nitrate transport to shoots, resulting in decreased nitrate content in edible parts of seedlings. During postharvest storage of tomatoes, HRW 
can also decrease nitrite accumulation by either inhibiting or enhancing the activities and transcripts of NR and nitrite reductase (NiR), respectively [47].

\subsection{Modulation of Ion Homeostasis}

Ion homeostasis plays an important role in plant tolerance to drought, salinity, and heavy metal stress [93]. It has been observed that $\mathrm{NH}_{3} \cdot \mathrm{BH}_{3}$ can decrease $\mathrm{Na}$ content and increase $\mathrm{K}$ content, resulting in a decreased $\mathrm{Na} / \mathrm{K}$ ratio in rapeseed seedling roots subjected to $\mathrm{NaCl}$ stress [29] (Table 5). Moreover, $\mathrm{NaCl}$-induced transcript levels of $\mathrm{Na}^{+}$transporter (BnSOS1 and BnNHX1) and $\mathrm{K}^{+}$transporter (BnKT1) were strengthened by $\mathrm{NH}_{3} \cdot \mathrm{BH}_{3}$. High levels of net $\mathrm{Na}^{+}$efflux and $\mathrm{H}^{+}$influx and lower net $\mathrm{K}^{+}$efflux were observed in $\mathrm{NH}_{3} \cdot \mathrm{BH}_{3}-$ treated seedling roots. This $\mathrm{NH}_{3} \cdot \mathrm{BH}_{3}$-rebuilt ion homeostasis was closely associated with NO signaling.

Table 5. Roles of $\mathrm{H}_{2}$ involved in modulation of ion homeostasis in horticultural crops.

\begin{tabular}{|c|c|c|c|c|c|c|}
\hline Materials & $\begin{array}{l}\text { Treatment } \\
\text { Stage }\end{array}$ & $\begin{array}{c}\mathrm{H}_{2} \text { Delivery Methods } \\
\text { and Treatment }\end{array}$ & $\begin{array}{c}\text { Effective } \\
\text { Concentration of } \\
\mathrm{H}_{2}\end{array}$ & Functions of $\mathbf{H}_{2}$ & Mechanism & Ref. No. \\
\hline $\begin{array}{l}\text { Brassica rapa var. } \\
\text { chinensis } \\
\text { 'Dongfang 2' }\end{array}$ & Preharvest & $\begin{array}{l}1 / 4 \text { Hoagland's nutrient } \\
\text { solution with } \mathrm{H}_{2} ; \text { the } \\
\text { seedlings were pretreated } \\
\text { for } 1 \mathrm{~d} \text { (replaced every } 12 \mathrm{~h} \text { ) }\end{array}$ & $\begin{array}{l}\text { Not shown }(50 \% \\
\text { saturation HRW) }\end{array}$ & $\begin{array}{l}\text { Reduces } \\
\text { cadmium } \\
\text { accumulation }\end{array}$ & $\begin{array}{c}\text { Inhibits the expression } \\
\text { of } B c I R T 1 \text { and } B c Z I P 2, \\
\text { and reduces cadmium } \\
\text { absorption }\end{array}$ & {$[94,95]$} \\
\hline $\begin{array}{c}\text { Brassica napus } \\
\text { 'Zhongshuang 11' }\end{array}$ & Preharvest & $\begin{array}{c}\text { Ammonia borane } \\
\left(\mathrm{NH}_{3} \cdot \mathrm{BH}_{3} ; 2 \mathrm{mg} / \mathrm{L}\right) ; \text { the } \\
\text { seedlings were incubated } \\
\text { for } 3 \mathrm{~d} \text { (changed daily) } \\
\text { under } \mathrm{NaCl} \text {, PEG, or } \\
\mathrm{Cd} \text { stress }\end{array}$ & $\sim 300 \mu \mathrm{M}$ & $\begin{array}{l}\text { Enhances the } \\
\text { tolerance against } \\
\text { salinity, drought, } \\
\text { or cadmium }\end{array}$ & $\begin{array}{l}\text { Decreases cell death } \\
\text { rebuilds redox and ion } \\
\text { homeostasis, increases } \\
\text { proline content, thus } \\
\text { reducing cadmium } \\
\text { absorption and } \\
\text { accumulation }\end{array}$ & [29] \\
\hline $\begin{array}{l}\text { Cucumis satious } \\
\text { 'Xinchun } 4 '\end{array}$ & Preharvest & $\begin{array}{l}\text { HRW }(450 \mu \mathrm{M}) ; \text { the } \\
\text { seedlings incubated for } \\
2 / 5 \mathrm{~d} \text { (changed daily) }\end{array}$ & $\sim 450 \mu \mathrm{M}$ & $\begin{array}{l}\text { Induces } \\
\text { adventitious } \\
\text { rooting }\end{array}$ & $\begin{array}{l}\text { Regulates the protein } \\
\text { and gene expressions of } \\
\text { PM H+-ATPase and } \\
\text { 14-3-3 mediated by NO. }\end{array}$ & [96] \\
\hline
\end{tabular}

HRW can also reduce $\mathrm{Cd}$ absorption by regulating the metal ion transporters in pak choi seedlings. BcIRT1 (iron-regulated transporter 1) and BcZIP2 (zinc-regulated transporter protein 2) are the main $\mathrm{Cd}$ transporters selected in pak choi, which have the ability to transport $\mathrm{Cd}^{2+}, \mathrm{Mn}^{2+}, \mathrm{Zn}^{2+}$, and $\mathrm{Fe}^{2+}$ [94]. In pak choi and wild-type (Col-0) and transgenic Arabidopsis of IRT1 and ZIP2, Cd concentrations were significantly reduced by HRW, except for the irt1-mutant and zip2-mutant. Meanwhile, HRW decreased $\mathrm{Cd}^{2+}$ influx in roots of WT and transgenic lines, along with enhancing the competition between $\mathrm{Zn}$ and $\mathrm{Cd}$ [95].

In addition, $\mathrm{H}_{2}$ can regulate the interaction of $\mathrm{PM} \mathrm{H}^{+}$-ATPase and 14-3-3 proteins [96]. However, whether there are $\mathrm{H}_{2}$ targets on the cell membrane is worthy of further investigation.

\section{6. $\mathrm{H}_{2}$ Is Involved in Phytohormones Signaling}

Abscisic acid (ABA), ethylene (ETH), and jasmonate acid (JA) can induce $\mathrm{H}_{2}$, but the specific biosynthesis pathway has yet to be elucidated [31,97]. For alfalfa drought response, $\mathrm{H}_{2}$ acted as a positive regulator in the ABA signaling cascade to regulate stomatal movement [97] (Table 6). $\mathrm{H}_{2}$-modified apoplastic $\mathrm{pH}$ by $\mathrm{H}^{+}$-ATPase might be involved in this signaling process. Moreover, $\mathrm{H}_{2}$ differentially increased the transcriptional factor genes involved in ABA signaling, including MYB102, MYC2, and ABF / AREB2 [98].

HRW also increased gibberellin (GA) and indolylacetic acid (IAA) contents in the hypocotyl and roots of mung beans, respectively, thus promoting the growth of seedlings [99]. These changes in phytohormones induced by HRW indicated tissue specificity. Similarly, Zeng et al. [31] reported that HRW-induced changes in the transcription of phytohormones were greater in shoots than in roots, suggesting that the interaction of $\mathrm{H}_{2}$ and GA and IAA might be in a tissue-dependent manner. Moreover, HRW regulated auxin signaling- 
related and adventitious rooting-related genes, such as CsDNAJ-1, CsCDPK1/5, CsCDC6, CsAUX22B-like, and CsAUX22D-like, via the modulation of HO-1 in cucumber explants [12]. It has also been observed that soaking freesia bulbs and/or irrigating with HRW can increase IAA, zeatin nucleoside, and GA contents, with reduced ABA content in the flower stalks resulting in early flowering, increased length, and diameter of flower stalks, as well as increased diameter and number of florets [45].

ETH is a pleiotropic phytohormone, involving in a variety of developmental processes, such as rooting, ripening, and senescence in plants. A previous study reported that ETH may be another downstream signaling molecule in $\mathrm{H}_{2}$-promoted cucumber adventitious root formation [100]. Meanwhile, RuBisCO, SBPase, and OEE1 (photosynthesis-related proteins); TDH (amino acid metabolism-related protein); CAPX (stress response-related protein); and PDI (folding, modification, and degradation-related protein) might play important roles during these processes. In addition, both $\mathrm{H}_{2}$ gas and $\mathrm{HRW}$ can inhibit ETH biosynthesis by decreasing 1-aminocyclopropene-1-carboxylate (ACC) concentration; ACC synthase and ACC oxidase (ACO) activities; and corresponding genes and ETH receptor gene (ETR1 and ETR3) transcriptions, resulting in delayed kiwifruit ripening [22] and cut rose flower senescence [49].

Therefore, the interactions between $\mathrm{H}_{2}$ and phytohormones are very complex, showing temporal and tissue specificity.

Table 6. Roles of $\mathrm{H}_{2}$ involved in phytohormones signaling in horticultural crops.

\begin{tabular}{|c|c|c|c|c|c|c|}
\hline Materials & $\begin{array}{l}\text { Treatment } \\
\text { Stage }\end{array}$ & $\begin{array}{c}\mathrm{H}_{2} \text { Delivery Methods } \\
\text { and Treatment }\end{array}$ & $\begin{array}{c}\text { Effective } \\
\text { Concentration of } \\
\mathrm{H}_{2} \\
\end{array}$ & Functions of $\mathrm{H}_{2}$ & Mechanism & Ref. No. \\
\hline $\begin{array}{l}\text { Medicago sativa } \\
\text { 'Victoria' }\end{array}$ & Preharvest & $\begin{array}{l}\text { HRW; the seedlings were } \\
\text { irrigated for } 7 \mathrm{~d} \text { before } \\
\text { 15-d drought treatment }\end{array}$ & $\begin{array}{l}\text { Not shown }(50 \% \\
\text { saturation HRW) }\end{array}$ & $\begin{array}{l}\text { Induces drought } \\
\text { tolerance }\end{array}$ & $\begin{array}{c}\text { Modulates stomatal } \\
\text { sensitivity to ABA and } \\
\text { Apoplastic pH }\end{array}$ & [97] \\
\hline $\begin{array}{l}\text { Medicago sativa } \\
\text { 'Victoria' }\end{array}$ & Preharvest & $\begin{array}{c}1 / 4 \text { Hoagland's nutrient } \\
\text { solution with } \mathrm{H}_{2}(780 \mu \mathrm{M} \\
\left.\mathrm{H}_{2}\right) \text {; the seedlings were } \\
\text { pretreated for } 12 \mathrm{~h}\end{array}$ & $\sim 390 \mu \mathrm{M}$ & $\begin{array}{l}\text { Induces tolerance } \\
\text { against osmotic } \\
\text { stress }\end{array}$ & $\begin{array}{l}\text { Involved in } \\
\text { phytohormone } \\
\text { signaling }\end{array}$ & [98] \\
\hline $\begin{array}{l}\text { Cucumis satious } \\
\text { 'Xinchun } 4 \text { ' }\end{array}$ & Preharvest & $\begin{array}{l}\text { HRW }(680 \mu \mathrm{M}) \text {; the } \\
\text { seedlings were incubated } \\
\text { for } 7 \mathrm{~d} \text { (changed daily) }\end{array}$ & $\sim 350 \mu \mathrm{M}$ & $\begin{array}{l}\text { Induces } \\
\text { adventitious } \\
\text { rooting }\end{array}$ & $\begin{array}{c}\text { Ethylene may be the } \\
\text { downstream signaling } \\
\text { molecule during } \\
\mathrm{H}_{2} \text {-induced } \\
\text { adventitious rooting, } \\
\text { and proteins RuBisCo, } \\
\text { SBPase, OEE1, TDH, } \\
\text { CAPX, and PDI may } \\
\text { play important roles }\end{array}$ & [100] \\
\hline $\begin{array}{l}\text { Cucumis satious } \\
\text { 'Lufeng' }\end{array}$ & Preharvest & $\begin{array}{c}\text { HRW }(220 \mu \mathrm{M}) \text {; incubated } \\
\text { for } 4 \mathrm{~d}\end{array}$ & $\sim 110 \mu \mathrm{M}$ & $\begin{array}{l}\text { Regulates } \\
\text { adventitious root } \\
\text { development }\end{array}$ & $\begin{array}{l}\text { Regulates HO-1 } \\
\text { signaling }\end{array}$ & [12] \\
\hline $\begin{array}{l}\text { Vigna radiata; } \\
\text { Cucumis sativus } \\
\text { 'Jinchun } 4 \text { '; } \\
\text { Raphanus sativus } \\
\text { 'Yanghua' }\end{array}$ & Preharvest & $\begin{array}{l}1 / 8 \text { strength Hoagland } \\
\text { nutrition solution with } \mathrm{H}_{2} \\
(800 \mu \mathrm{M}) ; \text { the seedlings } \\
\text { were incubated for } 5 \mathrm{~d} \\
\text { (replaced every } 12 \mathrm{~h} \text { ) }\end{array}$ & $\sim 480 \mu \mathrm{M}$ & $\begin{array}{l}\text { Promotes } \\
\text { elongation of } \\
\text { hypocotyls and } \\
\text { roots }\end{array}$ & $\begin{array}{l}\text { Increases GA and IAA } \\
\text { contents in the } \\
\text { hypocotyl and the root }\end{array}$ & [99] \\
\hline Vigna radiata & Preharvest & $\begin{array}{l}\text { HRW; seeds were soaked } \\
\text { for } 3 \mathrm{~d}\end{array}$ & $100 / 250 \mu \mathrm{M}$ & $\begin{array}{l}\text { Promotes the } \\
\text { growth of shoots } \\
\text { and roots }\end{array}$ & $\begin{array}{l}\text { Involved in } \\
\text { phytohormone } \\
\text { signaling }\end{array}$ & [31] \\
\hline Freesia refracta & Preharvest & $\begin{array}{l}\text { HRW }(75 \mu \mathrm{M}) \text {; the bulbs } \\
\text { were soaked for } 6 \mathrm{~h} \text {; } \\
\text { irrigated HRW at every } \\
7-10 \mathrm{~d} \text { and total } 3 \text { times } \\
\text { after scape sticking out }\end{array}$ & $\sim 37.5 \mu \mathrm{M}$ & $\begin{array}{l}\text { Promotes early } \\
\text { flowering; } \\
\text { increases the } \\
\text { number and } \\
\text { diameters of } \\
\text { florets }\end{array}$ & $\begin{array}{c}\text { Regulates } \\
\text { phytohormone and } \\
\text { soluble sugar content }\end{array}$ & [45] \\
\hline $\begin{array}{l}\text { Actinidia deliciosa } \\
\text { 'Xuxiang' }\end{array}$ & Postharvest & $\begin{array}{c}\text { Gas; the fruits were } \\
\text { fumigated for } \\
24 \mathrm{~h} / 12 \mathrm{~h}+12 \mathrm{~h}\end{array}$ & $\sim 0.2 \mu \mathrm{M}$ & $\begin{array}{l}\text { Prolongs the shelf } \\
\text { life }\end{array}$ & $\begin{array}{l}\text { Decreases ethylene } \\
\text { biosynthesis }\end{array}$ & [22] \\
\hline $\begin{array}{l}\text { Rosa chinensis } \\
\text { 'Movie star' }\end{array}$ & Postharvest & $\begin{array}{l}\text { HRW }(235 \mu \mathrm{M}) \text {; cut } \\
\text { flowers were incubated } \\
\text { for vase periods } \\
\text { (changed daily) }\end{array}$ & $\sim 2.35 \mu \mathrm{M}$ & $\begin{array}{l}\text { Alleviates } \\
\text { postharvest } \\
\text { senescence }\end{array}$ & $\begin{array}{l}\text { Inhibits ethylene } \\
\text { production and } \\
\text { alleviates ethylene } \\
\text { signal transduction }\end{array}$ & [49] \\
\hline
\end{tabular}




\section{Conclusions and Prospects}

Maintaining or increasing horticultural yield requires NPK fertilizers, manure, hazardous preservatives, or other polluting methods, which could be offset via cleaner or healthier alternatives. $\mathrm{H}_{2}$ is a carbon-free energy carrier that may be an attractive plant growth regulator for horticultural sustainability. Currently, over $95 \%$ of $\mathrm{H}_{2}$ is made by using fossil fuels, with the most common process of $\mathrm{H}_{2}$ production being steam methane reformation, which may produce $\mathrm{H}_{2}$ for $\sim \mathrm{USD} 1.15 / \mathrm{kg} \mathrm{H}_{2}$ in the US [101]. Other $\mathrm{H}_{2}$ production technologies, such as water electrolysis, are estimated to produce $\mathrm{H}_{2}$ for $\sim$ USD 5.50 per kilogram of $\mathrm{H}_{2}$. Although renewable $\mathrm{H}_{2}$ is relatively expensive, its production costs are reducing. According to the BloombergNEF's report of "Hydrogen Economy Outlook" [102], between 2014 and 2019, the cost of alkaline electrolyzers fell 40\% in North America and Europe, and systems made in China are already up to $80 \%$ cheaper than those made elsewhere. They forecast that renewable $\mathrm{H}_{2}$ could be produced for USD 0.7 to USD $1.6 / \mathrm{kg} \mathrm{H}_{2}$ in most parts of the world before 2050. Thus, the cost for applying $\mathrm{H}_{2}$ in horticulture is primarily dependent on the cost of labor, which is both feasible and affordable, at least under current economic conditions.

$\mathrm{H}_{2}$ has been applied in the above-mentioned important horticultural crops, confirming its positive effects both on plant growth, development, stress tolerance, and postharvest storage (Figure 3). A recent field trial has observed that $\mathrm{H}_{2}$ infusion increased $\mathrm{H}_{2}$-oxidizing bacteria activities, accompanied with an alteration of composition and structure of the microbial community [103]. However, the above effects of $\mathrm{H}_{2}$ on soil microbe were significantly influenced by environmental conditions, which would be taken into account in further $\mathrm{H}_{2}$ field trials. The potential negative effect of $\mathrm{H}_{2}$ on soil ecosystems should also be concerning. For example, $\mathrm{H}_{2}$ exposure may stimulate methane oxidation and the activities of pathogens that use $\mathrm{H}_{2}$ as an energy source [9]. Therefore, long-term and large-scale commercial field trials of $\mathrm{H}_{2}$ require further investigation, especially in the evaluation of resistance to pests and diseases, yield, and quality, as well as environmental impact. In addition, enhanced understanding is required with respect to the causal mechanisms underlying plant $\mathrm{H}_{2}$ production and action.

Overall, $\mathrm{H}_{2}$ has a substantial potential in horticultural applications to reduce fertilizer and pesticide use, providing higher-value and nutrient-rich horticultural crops. Since making technology cheap requires technological advance, we urge the cooperation of the industrial community. The next step may focus on practical application of $\mathrm{H}_{2}$ in horticulture.

Author Contributions: Conceptualization, W.S. and L.L.; writing-original draft preparation, L.L.; writing-review and editing, W.S., L.L., Y.Z. and X.C.; supervision, W.S.; project administration, W.S.; funding acquisition, W.S. All authors have read and agreed to the published version of the manuscript.

Funding: This research was funded by the National Natural Science Foundation of China (Grant No. 31972396), Air Liquide (China) R\&D Co., Ltd., Foshan Agriculture Science and Technology Project (Foshan City Budget No. 140, 2019.), and Center of Hydrogen Science, Shanghai Jiao Tong University, China.

Institutional Review Board Statement: Not applicable.

Informed Consent Statement: Not applicable.

Data Availability Statement: Not applicable.

Conflicts of Interest: The authors declare no conflict of interest.

\section{References}

1. López-García, P.; Moreira, D. The syntrophy hypothesis for the origin of eukaryotes revisited. Nat. Microbiol. 2020, 5, 655-667. [CrossRef]

2. Gaffron, H. Reduction of carbon dioxide with molecular hydrogen in green algæ. Nature 1939, 143, 204-205. [CrossRef]

3. Renwick, G.M.; Giumarro, C.; Siegel, S.M. Hydrogen metabolism in higher plants. Plant Physiol. 1964, 39, 303-306. [CrossRef]

4. Czerkawski, J.W. Fate of metabolic hydrogen in the rumen. Proc. Nutr. Soc. 1972, 31, 141-146. [CrossRef] 
5. Ohsawa, I.; Ishikawa, M.; Takahashi, K.; Watanabe, M.; Nishimaki, K.; Yamagata, K.; Katsura, K.; Katayama, Y.; Asoh, S.; Ohta, S. Hydrogen acts as a therapeutic antioxidant by selectively reducing cytotoxic oxygen radicals. Nat. Med. 2007, 13, 688-694. [CrossRef] [PubMed]

6. Xie, Y.; Mao, Y.; Lai, D.; Zhang, W.; Shen, W. $\mathrm{H}_{2}$ enhances arabidopsis salt tolerance by manipulating ZAT10/12-mediated antioxidant defence and controlling sodium exclusion. PLOS ONE 2012, 7, e49800. [CrossRef] [PubMed]

7. Russell, G.; Zulfiqar, F.; Hancock, J.T. Hydrogenases and the role of molecular hydrogen in plants. Plants 2020, 9, 1136. [CrossRef] [PubMed]

8. Constant, P.; Poissant, L.; Villemur, R. Tropospheric $\mathrm{H}_{2}$ budget and the response of its soil uptake under the changing environment. Sci. Total Environ. 2009, 407, 1809-1823. [CrossRef] [PubMed]

9. Piche-Choquette, S.; Constant, P. Molecular hydrogen, a neglected key driver of soil biogeochemical processes. Appl. Environ. Microbiol. 2019, 85, e02418-18. [CrossRef] [PubMed]

10. Dong, Z.; Wu, L.; Kettlewell, B.; Caldwell, C.D.; Layzell, D.B. Hydrogen fertilization of soils-Is this a benefit of legumes in rotation? Plant. Cell Environ. 2003, 26, 1875-1879. [CrossRef]

11. Jin, Q.; Zhu, K.; Cui, W.; Xie, Y.; Han, B.; Shen, W. Hydrogen gas acts as a novel bioactive molecule in enhancing plant tolerance to paraquat-induced oxidative stress via the modulation of heme oxygenase-1 signalling system. Plant Cell Environ. 2013, 36, 956-969. [CrossRef] [PubMed]

12. Lin, Y.; Zhang, W.; Qi, F.; Cui, W.; Xie, Y.; Shen, W. Hydrogen-rich water regulates cucumber adventitious root development in a heme oxygenase-1/carbon monoxide-dependent manner. J. Plant Physiol. 2014, 171, 1-8. [CrossRef]

13. Cao, Z.; Duan, X.; Yao, P.; Cui, W.; Cheng, D.; Zhang, J.; Jin, Q.; Chen, J.; Dai, T.; Shen, W. Hydrogen gas is involved in auxin-induced lateral root formation by modulating nitric oxide synthesis. Int. J. Mol. Sci. 2017, 18, 2084. [CrossRef] [PubMed]

14. Wu, Q.; Su, N.; Cai, J.; Shen, Z.; Cui, J. Hydrogen-rich water enhances cadmium tolerance in Chinese cabbage by reducing cadmium uptake and increasing antioxidant capacities. J. Plant Physiol. 2015, 175, 174-182. [CrossRef] [PubMed]

15. Cui, W.; Gao, C.; Fang, P.; Lin, G.; Shen, W. Alleviation of cadmium toxicity in Medicago sativa by hydrogen-rich water. J. Hazard. Mater. 2013, 260, 715-724. [CrossRef] [PubMed]

16. Hu, H.; Li, P.; Shen, W. Preharvest application of hydrogen-rich water not only affects daylily bud yield but also contributes to the alleviation of bud browning. Sci. Hortic. Amst. 2021, 287, 110267. [CrossRef]

17. Hu, H.; Li, P.; Wang, Y.; Gu, R. Hydrogen-rich water delays postharvest ripening and senescence of kiwifruit. Food Chem. 2014, 156, 100-109. [CrossRef] [PubMed]

18. Yun, Z.; Gao, H.; Chen, X.; Chen, Z.; Zhang, Z.; Li, T.; Qu, H.; Jiang, Y. Effects of hydrogen water treatment on antioxidant system of litchi fruit during the pericarp browning. Food Chem. 2021, 336, 127618. [CrossRef] [PubMed]

19. Ren, P.; Jin, X.; Liao, W.; Wang, M.; Niu, L.; Li, X.; Xu, X.; Zhu, Y. Effect of hydrogen-rich water on vase life and quality in cut lily and rose flowers. Hortic. Environ. Biote. 2017, 58, 576-584. [CrossRef]

20. Cai, M.; Du, H. Effects of hydrogen-rich water pretreatment on vase life of carnation (Dianthus caryophyllus) cut flowers. J. Shanghai Jiao Tong Univ. (Agric. Sci.) 2015, 33, 41-45. (In Chinese)

21. Jiang, K.; Kuang, Y.; Feng, L.; Liu, Y.; Wang, S.; Du, H.; Shen, W. Molecular hydrogen maintains the storage quality of chinese chive through improving antioxidant capacity. Plants 2021, 10, 1095. [CrossRef]

22. Hu, H.; Zhao, S.; Li, P.; Shen, W. Hydrogen gas prolongs the shelf life of kiwifruit by decreasing ethylene biosynthesis. Postharvest Biol. Tec. 2018, 135, 123-130. [CrossRef]

23. Zerveas, S.; Kydonakis, E.; Mente, M.; Daskalakis, V.; Kotzabasis, K. Hydrogen gas as a central on-off functional switch of reversible metabolic arrest-New perspectives for biotechnological applications. J. Biotechnol. 2021, 335, 9-18. [CrossRef] [PubMed]

24. Safonov, V.L.; Khitrin, A.K. Hydrogen nanobubbles in a water solution of dietary supplement. Colloid. Surface. A 2013, 436, 333-336. [CrossRef]

25. Li, L.; Liu, Y.; Wang, S.; Zou, J.; Ding, W.; Shen, W. Magnesium hydride-mediated sustainable hydrogen supply prolongs the vase life of cut carnation flowers via hydrogen sulfide. Front. Plant Sci. 2020, 11, 595376. [CrossRef] [PubMed]

26. Li, L.; Yin, Q.; Zhang, T.; Cheng, P.; Xu, S.; Shen, W. Hydrogen nanobubble water delays petal senescence and prolongs the vase life of cut carnation (Dianthus caryophyllus L.) Flowers. Plants 2021, 10, 1662. [CrossRef] [PubMed]

27. Hirscher, M.; Yartys, V.A.; Baricco, M.; Bellosta Von Colbe, J.; Blanchard, D.; Bowman, R.C.; Broom, D.P.; Buckley, C.E.; Chang, F.; Chen, P.; et al. Materials for hydrogen-based energy storage-Past, recent progress and future outlook. J. Alloy. Compd. 2020, 827, 153548. [CrossRef]

28. Li, Y.; Li, L.; Wang, S.; Liu, Y.; Zou, J.; Ding, W.; Du, H.; Shen, W. Magnesium hydride acts as a convenient hydrogen supply to prolong the vase life of cut roses by modulating nitric oxide synthesis. Postharvest Biol. Tec. 2021, 177, 111526. [CrossRef]

29. Zhao, G.; Cheng, P.; Zhang, T.; Abdalmegeed, D.; Xu, S.; Shen, W. Hydrogen-rich water prepared by ammonia borane can enhance rapeseed (Brassica napus L.) seedlings tolerance against salinity, drought or cadmium. Ecotox. Environ. Safe. 2021, 224, 112640. [CrossRef] [PubMed]

30. Wang, Y.; Lv, P.; Kong, L.; Shen, W.; He, Q. Nanomaterial-mediated sustainable hydrogen supply induces lateral root formation via nitrate reductase-dependent nitric oxide. Chem. Eng. J. 2021, 405, 126905. [CrossRef]

31. Zeng, J.; Zhang, M.; Sun, X.; Meijler, M.M. Molecular hydrogen is involved in phytohormone signaling and stress responses in plants. PLOS ONE 2013, 8, e71038. 
32. Chen, Q.; Zhao, X.; Lei, D.; Hu, S.; Shen, Z.; Shen, W.; Xu, X. Hydrogen-rich water pretreatment alters photosynthetic gas exchange, chlorophyll fluorescence, and antioxidant activities in heat-stressed cucumber leaves. Plant Growth Regul. 2017, 83, 69-82. [CrossRef]

33. Liu, F.; Cai, B.; Sun, S.; Bi, H.; Ai, X. Effect of hydrogen-rich water soaked cucumber seeds on cold tolerance and its physiological mechanism in cucumber seedlings. Sci. Agric. Sin. 2017, 50, 881-889. (In Chinese)

34. Chen, Y.; Wang, M.; Hu, L.; Liao, W.; Dawuda, M.M.; Li, C. Carbon monoxide is involved in hydrogen gas-induced adventitious root development in cucumber under simulated drought stress. Front. Plant Sci. 2017, 8, 128. [CrossRef]

35. Liu, F.; Lou, W.; Wang, J.; Li, Q.; Shen, W. Glutathione produced by $\gamma$-glutamyl cysteine synthetase acts downstream of hydrogen to positively influence lateral root branching. Plant Physiol. Bioch. 2021, 167, 68-76. [CrossRef] [PubMed]

36. Zhu, Y.; Liao, W. The metabolic constituent and rooting-related enzymes responses of marigold explants to hydrogen gas during adventitious root development. Theor. Exp. Plant Phys. 2017, 29, 77-85. [CrossRef]

37. Su, N.; Wu, Q.; Liu, Y.; Cai, J.; Shen, W.; Xia, K.; Cui, J. Hydrogen-rich water reestablishes ROS homeostasis but exerts differential effects on anthocyanin synthesis in two varieties of radish sprouts under UV-A irradiation. J. Agr. Food Chem. 2014, 62, 6454-6462. [CrossRef] [PubMed]

38. Jin, Q.; Cui, W.; Dai, C.; Zhu, K.; Zhang, J.; Wang, R.; La, H.; Li, X.; Shen, W. Involvement of hydrogen peroxide and heme oxygenase-1 in hydrogen gas-induced osmotic stress tolerance in alfalfa. Plant Growth Regul. 2016, 80, 215-223. [CrossRef]

39. Wu, Q.; Su, N.; Chen, Q.; Shen, W.; Shen, Z.; Xia, Y.; Cui, J. Cadmium-induced hydrogen accumulation is involved in cadmium tolerance in Brassica campestris by reestablishment of reduced glutathione homeostasis. PLoS ONE 2015, 10, e139956.

40. Cui, W.; Fang, P.; Zhu, K.; Mao, Y.; Gao, C.; Xie, Y.; Wang, J.; Shen, W. Hydrogen-rich water confers plant tolerance to mercury toxicity in alfalfa seedlings. Ecotox. Environ. Safe. 2014, 105, 103-111. [CrossRef]

41. Chen, M.; Cui, W.; Zhu, K.; Xie, Y.; Zhang, C.; Shen, W. Hydrogen-rich water alleviates aluminum-induced inhibition of root elongation in alfalfa via decreasing nitric oxide production. J. Hazard. Mater. 2014, 267, 40-47. [CrossRef]

42. Ren, A.; Liu, R.; Miao, Z.; Zhang, X.; Cao, P.; Chen, T.; Li, C.; Shi, L.; Jiang, A.; Zhao, M. Hydrogen-rich water regulates effects of ROS balance on morphology, growth and secondary metabolism via glutathione peroxidase in Ganoderma lucidum. Environ. Microbiol. 2017, 19, 566-583. [CrossRef]

43. Zhang, J.; Hao, H.; Chen, M.; Wang, H.; Feng, Z.; Chen, H. Hydrogen-rich water alleviates the toxicities of different stresses to mycelial growth in Hypsizygus marmoreus. Amb. Express. 2017, 7, 107. [CrossRef] [PubMed]

44. Wei, X.; Chen, J.; Chen, H.; Wu, X.; Tian, J.; Su, N.; Cui, J. Hydrogen-rich water ameliorates the toxicity induced by $\mathrm{Ca}\left(\mathrm{NO}_{3}\right)_{2}$ excess through enhancing antioxidant capacities and re-establishing nitrate homeostasis in Brassica campestris spp. chinensis $\mathrm{L}$ seedlings. Acta. Physiol. Plant 2021, 43, 50. [CrossRef]

45. Song, Y.; Li, C.; Xie, P.; Cong, F.; Du, H. Effects of application on stage and methods of hydrogen-rich water on blossom of freesia (Fressia refracta) and related physiological mechanisms. J. Shanghai Jiao Tong Univ. (Agric. Sci.) 2017, 35, 10-16. (In Chinese)

46. Chen, H.; Zhang, J.; Hao, H.; Feng, Z.; Chen, M.; Wang, H.; Ye, M. Hydrogen-rich water increases postharvest quality by enhancing antioxidant capacity in Hypsizygus marmoreus. Amb. Express. 2017, 7, 221. [CrossRef] [PubMed]

47. Zhang, Y.; Zhao, G.; Cheng, P.; Yan, X.; Li, Y.; Cheng, D.; Wang, R.; Chen, J.; Shen, W. Nitrite accumulation during storage of tomato fruit as prevented by hydrogen gas. Int. J. Food Prop. 2019, 22, 1425-1438. [CrossRef]

48. Zhao, X.; Meng, X.; Li, W.; Cheng, R.; Wu, H.; Liu, P.; Ma, M. Effect of hydrogen-rich water and slightly acidic electrolyzed water treatments on storage and preservation of fresh-cut kiwifruit. J. Food Meas. 2021, 15, 5203-5210. [CrossRef]

49. Wang, C.; Fang, H.; Gong, T.; Zhang, J.; Niu, L.; Huang, D.; Huo, J.; Liao, W. Hydrogen gas alleviates postharvest senescence of cut rose 'Movie star' by antagonizing ethylene. Plant Mol. Biol. 2020, 102, 271-285. [CrossRef] [PubMed]

50. Huo, J.; Huang, D.; Zhang, J.; Fang, H.; Wang, B.; Wang, C.; Ma, Z.; Liao, W. Comparative proteomic analysis during the involvement of nitric oxide in hydrogen gas-improved postharvest freshness in cut lilies. Int. J. Mol. Sci. 2018, 19, 3955. [CrossRef] [PubMed]

51. Song, Y.; Cong, F.; Li, C.; Du, H. Effects of hydrogen-rich water pretreatment on vase life and antioxidant system in cut freesia. J. Shanghai Jiao Tong Univ. (Agric. Sci.) 2018, 36, 1-6. (In Chinese)

52. Su, J.; Nie, Y.; Zhao, G.; Cheng, D.; Wang, R.; Chen, J.; Zhang, S.; Shen, W. Endogenous hydrogen gas delays petal senescence and extends the vase life of lisianthus cut flowers. Postharvest Biol. Tec. 2019, 147, 148-155. [CrossRef]

53. Su, N.; Wu, Q.; Chen, H.; Huang, Y.; Zhu, Z.; Chen, Y.; Cui, J. Hydrogen gas alleviates toxic effects of cadmium in Brassica campestris seedlings through up-regulation of the antioxidant capacities: Possible involvement of nitric oxide. Environ. Pollut. 2019, 251, 45-55. [CrossRef]

54. Wu, Q.; Huang, L.; Su, N.; Shabala, L.; Wang, H.; Huang, X.; Wen, R.; Yu, M.; Cui, J.; Shabala, S. Calcium-dependent hydrogen peroxide mediates hydrogen-rich water-reduced cadmium uptake in plant roots. Plant Physiol. 2020, 183, 1331-1344. [CrossRef] [PubMed]

55. Fang, H.; Wang, C.; Wang, S.; Liao, W. Hydrogen gas increases the vase life of cut rose 'Movie star' by regulating bacterial community in the stem ends. Postharvest Biol. Tec. 2021, 181, 111685. [CrossRef]

56. Sandhya. Modified atmosphere packaging of fresh produce: Current status and future needs. LWT-Food Sci. Technol. 2010, 43, 381-392. [CrossRef]

57. Brizzolara, S.; Manganaris, G.A.; Fotopoulos, V.; Watkins, C.B.; Tonutti, P. Primary metabolism in fresh fruits during storage. Front. Plant Sci. 2020, 11, 80. [CrossRef] 
58. Golding, J.B.; Shearer, D.; Wyllie, S.G.; McGlasson, W.B. Application of 1-MCP and propylene to identify ethylene-dependent ripening processes in mature banana fruit. Postharvest Biol. Tec. 1998, 14, 87-98. [CrossRef]

59. Huang, X.; Chaparro, J.M.; Reardon, K.F.; Zhang, R.; Shen, Q.; Vivanco, J.M. Rhizosphere interactions: Root exudates, microbes, and microbial communities. Botany 2014, 92, 267-275. [CrossRef]

60. Dong, Z.; Layzell, D.B. $\mathrm{H}_{2}$ oxidation, $\mathrm{O}_{2}$ uptake and $\mathrm{CO}_{2}$ fixation in hydrogen treated soils. Plant Soil 2001, 229, 1-12. [CrossRef]

61. Maimaiti, J.; Zhang, Y.; Yang, J.; Cen, Y.; Layzell, D.B.; Peoples, M.; Dong, Z. Isolation and characterization of hydrogen-oxidizing bacteria induced following exposure of soil to hydrogen gas and their impact on plant growth. Environ. Microbiol. 2007, 9, 435-444. [CrossRef]

62. Irvine, P.; Smith, M.; Dong, Z. Hydrogen fertilizer: Bacteria or fungi? Acta Hortic. 2004, 239-242. [CrossRef]

63. McLearn, N.; Dong, Z. Microbial nature of the hydrogen-oxidizing agent in hydrogen-treated soil. Biol. Fert. Soils 2002, 35, 465-469. [CrossRef]

64. Zhang, Y.; He, X.; Dong, Z. Effect of hydrogen on soil bacterial community structure in two soils as determined by terminal restriction fragment length polymorphism. Plant Soil 2009, 320, 295-305. [CrossRef]

65. Flynn, B.; Graham, A.; Scott, N.; Layzell, D.B.; Dong, Z. Nitrogen fixation, hydrogen production and $\mathrm{N}_{2} \mathrm{O}$ emissions. Can. J. Plant Sci. 2014, 94, 1037-1041. [CrossRef]

66. Liu, H.; Wang, W.; Cao, G.; Tang, M. Effect of hydrogen on microbial population and enzyme activity in Robinia pseudoacacia rhizosphere soil. Chin. J. Appl. Environ. Biol. 2010, 16, 515-518. (In Chinese)

67. Williamson, B.; Tudzynsk, B.; Tudzynski, P.; van Kan, J.A.L. Botrytis cinerea: The cause of grey mould disease. Mol. Plant Pathol. 2007, 8, 561-580. [CrossRef] [PubMed]

68. Lu, H.; Wu, B.; Wang, Y.; Liu, N.; Meng, F.; Hu, Z.; Zhao, R.; Zhao, H. Effects of hydrogen-rich water treatment on defense responses of postharvest tomato fruit to Botrytis cinerea. J. Henan Agric. Sci. 2017, 46, 64-68. (In Chinese)

69. Zhou, X.; Joshi, S.; Patil, S.; Khare, T.; Kumar, V. Reactive oxygen, nitrogen, carbonyl and sulfur species and their roles in plant abiotic stress responses and tolerance. J. Plant Growth Regul. 2021. [CrossRef]

70. Su, J.; Zhang, Y.; Nie, Y.; Cheng, D.; Wang, R.; Hu, H.; Chen, J.; Zhang, J.; Du, Y.; Shen, W. Hydrogen-induced osmotic tolerance is associated with nitric oxide-mediated proline accumulation and reestablishment of redox balance in alfalfa seedlings. Environ. Exp. Bot. 2018, 147, 249-260. [CrossRef]

71. Wang, B.; Bian, B.; Wang, C.; Li, C.; Fang, H.; Zhang, J.; Huang, D.; Huo, J.; Liao, W. Hydrogen gas promotes the adventitious rooting in cucumber under cadmium stress. PLoS ONE 2019, 14, e212639. [CrossRef]

72. Del Rio, L.A. ROS and RNS in plant physiology: An overview. J. Exp. Bot. 2015, 66, 2827-2837. [CrossRef] [PubMed]

73. Zhu, Y.; Liao, W.; Niu, L.; Wang, M.; Ma, Z. Nitric oxide is involved in hydrogen gas-induced cell cycle activation during adventitious root formation in cucumber. BMC Plant Biol. 2016, 16, 146. [CrossRef]

74. Zhu, Y.; Liao, W.; Wang, M.; Niu, L.; Xu, Q.; Jin, X. Nitric oxide is required for hydrogen gas-induced adventitious root formation in cucumber. J. Plant Physiol. 2016, 195, 50-58. [CrossRef] [PubMed]

75. Maruyama-Nakashita, A.; Ohkama-Ohtsu, N. Sulfur assimilation and glutathione metabolism in plants. In Glutathione in Plant Growth, Development, and Stress Tolerance; Hossain, M.A., Mostofa, M.G., Diaz-Vivancos, P., Burritt, D.J., Fujita, M., Tran, L.P., Eds.; Springer International Publishing: Cham, Switzerland, 2017; pp. 287-308.

76. Cui, W.; Yao, P.; Pan, J.; Dai, C.; Cao, H.; Chen, Z.; Zhang, S.; Xu, S.; Shen, W. Transcriptome analysis reveals insight into molecular hydrogen-induced cadmium tolerance in alfalfa: The prominent role of sulfur and (homo)glutathione metabolism. BMC Plant Biol. 2020, 20, 58. [CrossRef] [PubMed]

77. Dai, C.; Cui, W.; Pan, J.; Xie, Y.; Wang, J.; Shen, W. Proteomic analysis provides insights into the molecular bases of hydrogen gas-induced cadmium resistance in Medicago sativa. J. Proteomics 2017, 152, 109-120. [CrossRef] [PubMed]

78. Li, C.; Shi, L.; Chen, D.; Ren, A.; Gao, T.; Zhao, M. Functional analysis of the role of glutathione peroxidase (GPx) in the ROS signaling pathway, hyphal branching and the regulation of ganoderic acid biosynthesis in Ganoderma lucidum. Fungal Genet. Biol. 2015, 82, 168-180. [CrossRef] [PubMed]

79. Corpas, F.J.; Palma, J.M. $\mathrm{H}_{2} \mathrm{~S}$ signaling in plants and applications in agriculture. J. Adv. Res. 2020, 24, 131-137. [CrossRef]

80. da-Silva, C.J.; Modolo, L.V. Hydrogen sulfide: A new endogenous player in an old mechanism of plant tolerance to high salinity. Acta Bot. Bras. 2017, 32, 150-160. [CrossRef]

81. Zhang, Y.; Cheng, P.; Wang, Y.; Li, Y.; Su, J.; Chen, Z.; Yu, X.; Shen, W. Genetic elucidation of hydrogen signaling in plant osmotic tolerance and stomatal closure via hydrogen sulfide. Free Radical Bio. Med. 2020, 161, 1-14. [CrossRef] [PubMed]

82. Buer, C.S.; Imin, N.; Djordjevic, M.A. Flavonoids: New roles for old molecules. J. Integr Plant Biol 2010, 52, 98-111. [CrossRef] [PubMed]

83. Xie, Y.; Zhang, W.; Duan, X.; Dai, C.; Zhang, Y.; Cui, W.; Wang, R.; Shen, W. Hydrogen-rich water-alleviated ultraviolet-B-triggered oxidative damage is partially associated with the manipulation of the metabolism of (iso)flavonoids and antioxidant defence in Medicago sativa. Funct. Plant Biol. 2015, 42, 1141. [CrossRef] [PubMed]

84. Liu, Y.; Tikunov, Y.; Schouten, R.E.; Marcelis, L.F.M.; Visser, R.G.F.; Bovy, A. Anthocyanin biosynthesis and degradation mechanisms in solanaceous vegetables: A review. Front. Chem. 2018, 6, 52. [CrossRef] [PubMed]

85. Khoo, H.E.; Azlan, A.; Tang, S.T.; Lim, S.M. Anthocyanidins and anthocyanins: Colored pigments as food, pharmaceutical ingredients, and the potential health benefits. Food Nutr. Res. 2017, 61, 1361779. [CrossRef] 
86. Zhang, X.; Wei, J.; Huang, Y.; Shen, W.; Chen, X.; Lu, C.; Su, N.; Cui, J. Increased cytosolic calcium contributes to hydrogen-rich water-promoted anthocyanin biosynthesis under UV-A irradiation in radish sprouts hypocotyls. Front. Plant Sci 2018, 9, 1020. [CrossRef]

87. Zhang, X.; Su, N.; Jia, L.; Tian, J.; Li, H.; Huang, L.; Shen, Z.; Cui, J. Transcriptome analysis of radish sprouts hypocotyls reveals the regulatory role of hydrogen-rich water in anthocyanin biosynthesis under UV-A. BMC Plant Biol. 2018, 18, 227. [CrossRef]

88. Zhang, X.; Wei, J.; Tian, J.; Li, N.; Jia, L.; Shen, W.; Cui, J. Enhanced anthocyanin accumulation of immature radish microgreens by hydrogen-rich water under short wavelength light. Sci. Hortic. Amst. 2019, 247, 75-85. [CrossRef]

89. Panche, A.N.; Diwan, A.D.; Chandra, S.R. Flavonoids: An overview. J. Nutr Sci 2016, 5, e47. [CrossRef] [PubMed]

90. Liu, F.; Zhang, X.; Li, D.; Zhai, J.; Bi, H.; Ai, X. Effect of exogenous hydrogen on photosynthetic carbon assimilation and nitrogen metabolism of cucumber seedlings under low temperature. Acta Hortic Sin. 2020, 47, 287-300. (In Chinese)

91. Han, J.; Shi, J.; Zeng, L.; Xu, J.; Wu, L. Effects of nitrogen fertilization on the acidity and salinity of greenhouse soils. Environ. Sci. Pollut. Res. 2015, 22, 2976-2986. [CrossRef] [PubMed]

92. Toyoizumi, T.; Sekiguchi, H.; Takabayashi, F.; Deguchi, Y.; Masuda, S.; Kinae, N. Induction effect of coadministration of soybean isoflavones and sodium nitrite on DNA damage in mouse stomach. Food Chem. Toxicol. 2010, 48, 2585-2591. [CrossRef] [PubMed]

93. Zhu, J. Abiotic stress signaling and responses in plants. Cell 2016, 167, 313-324. [CrossRef] [PubMed]

94. Wu, X.; Zhu, Z.B.; Chen, J.H.; Huang, Y.F.; Liu, Z.L.; Zou, J.W.; Chen, Y.H.; Su, N.N.; Cui, J. Transcriptome analysis revealed pivotal transporters involved in the reduction of cadmium accumulation in pak choi (Brassica chinensis L.) by exogenous hydrogen-rich water. Chemosphere 2019, 216, 684-697. [CrossRef]

95. Wu, X.; Su, N.; Yue, X.; Fang, B.; Zou, J.; Chen, Y.; Shen, Z.; Cui, J. IRT1 and ZIP2 were involved in exogenous hydrogen-rich water-reduced cadmium accumulation in Brassica chinensis and Arabidopsis thaliana. J. Hazard. Mater. 2021, 407, 124599. [CrossRef] [PubMed]

96. Li, C.; Huang, D.; Wang, C.; Wang, N.; Yao, Y.; Li, W.; Liao, W. NO is involved in $\mathrm{H}_{2}$-induced adventitious rooting in cucumber by regulating the expression and interaction of plasma membrane $\mathrm{H}^{+}$-ATPase and 14-3-3. Planta 2020, 252, 9. [CrossRef] [PubMed]

97. Jin, Q.; Zhu, K.; Cui, W.; Li, L.; Shen, W. Hydrogen-modulated stomatal sensitivity to abscisic acid and drought tolerance via the regulation of apoplastic $\mathrm{pH}$ in Medicago sativa. J. Plant Growth Regul. 2016, 35, 565-573. [CrossRef]

98. Felix, K.; Su, J.; Lu, R.; Zhao, G.; Cui, W.; Wang, R.; Mu, H.; Cui, J.; Shen, W. Hydrogen-induced tolerance against osmotic stress in alfalfa seedlings involves ABA signaling. Plant Soil 2019, 445, 409-423. [CrossRef]

99. Wu, Q.; Su, N.; Huang, X.; Ling, X.; Yu, M.; Cui, J.; Shabala, S. Hydrogen-rich water promotes elongation of hypocotyls and roots in plants through mediating the level of endogenous gibberellin and auxin. Funct. Plant Biol. 2020, 47, 771. [CrossRef] [PubMed]

100. Huang, D.; Bian, B.; Zhang, M.; Wang, C.; Li, C.; Liao, W. The role and proteomic analysis of ethylene in hydrogen gas-induced adventitious rooting development in cucumber (Cucumis sativus L.) explants. PeerJ 2020, 8, e8896. [CrossRef]

101. Finke, C.E.; Leandri, H.F.; Karumb, E.T.; Zheng, D.; Hoffmann, M.R.; Fromer, N.A. Economically advantageous pathways for reducing greenhouse gas emissions from industrial hydrogen under common, current economic conditions. Energ. Environ. Sci. 2021, 14, 1517-1529. [CrossRef]

102. BNEF-Hydrogen-Economy-Outlook-Key-Messages-30-Mar-2020. Available online: https://data.bloomberglp.com/professional/ sites / 24/BNEF-Hydrogen-Economy-Outlook-Key-Messages-30-Mar-2020.pdf (accessed on 13 November 2021).

103. Wang, X.B.; Schmidt, R.; Yergeau, É.; Constant, P. Field $\mathrm{H}_{2}$ infusion alters bacterial and archaeal communities but not fungal communities nor nitrogen cycle gene abundance. Soil Biol. Biochem. 2020, 151, 108018. [CrossRef] 